\title{
The role of ozone atmosphere-snow gas exchange on polar, boundary-layer tropospheric ozone - a review and sensitivity analysis
}

\author{
D. Helmig ${ }^{1}$, L. Ganzeveld ${ }^{2}$, T. Butler ${ }^{2}$, and S. J. Oltmans ${ }^{3}$ \\ ${ }^{1}$ Institute of Arctic and Alpine Research (INSTAAR), University of Colorado, Boulder, CO 80309-0450, USA \\ ${ }^{2}$ Max-Plank Institute for Chemistry, Department of Atmospheric Chemistry, Joachim-Becher-Weg 27, 55020 Mainz, \\ Germany \\ ${ }^{3}$ Global Monitoring Devision (GMD), National Oceanic and Atmospheric Administration (NOAA), 325 Broadway, Boulder, \\ CO 80303, USA
}

Received: 31 October 2005 - Published in Atmos. Chem. Phys. Discuss.: 25 January 2006

Revised: 9 November 2006 - Accepted: 27 November 2006 - Published: 5 January 2007

\begin{abstract}
Recent research on snowpack processes and atmosphere-snow gas exchange has demonstrated that chemical and physical interactions between the snowpack and the overlaying atmosphere have a substantial impact on the composition of the lower troposphere. These observations also imply that ozone deposition to the snowpack possibly depends on parameters including the quantity and composition of deposited trace gases, solar irradiance, snow temperature and the substrate below the snowpack. Current literature spans a remarkably wide range of ozone deposition velocities $\left(\mathrm{v}_{d \mathrm{O}_{3}}\right)$; several studies even reported positive ozone fluxes out of the snow. Overall, published values range from $\sim-3<\mathrm{v}_{d 03}<2 \mathrm{~cm} \mathrm{~s}^{-1}$, although most data are within $0<\mathrm{v}_{d \mathrm{O} 3}<0.2 \mathrm{~cm} \mathrm{~s}^{-1}$. This literature reveals a high uncertainty in the parameterization and the magnitude of ozone fluxes into (and possibly out of) snow-covered landscapes. In this study a chemistry and tracer transport model was applied to evaluate the applicability of the published $\mathrm{v}_{d \mathrm{O}}$ and to investigate the sensitivity of tropospheric ozone towards ozone deposition over Northern Hemisphere snow-covered land and sea-ice. Model calculations using increasing $\mathrm{v}_{d} \mathrm{O} 3$ of $0.0,0.01,0.05$ and $0.10 \mathrm{~cm} \mathrm{~s}^{-1}$ resulted in general ozone sensitivities up to $20-30 \%$ in the Arctic surface layer, and of up to $130 \%$ local increases in selected Northern Latitude regions. The simulated ozone concentrations were compared with mean January ozone observations from 18 Arctic stations. Best agreement between the model and observations, not only in terms of absolute concentrations but also in the hourly ozone variability, was found by applying an ozone deposition velocity in the range of $0.00-0.01 \mathrm{~cm} \mathrm{~s}^{-1}$, which is smaller than most literature data and also significantly
\end{abstract}

Correspondence to: D. Helmig

(detlev.helmig@colorado.edu) lower compared to the value of $0.05 \mathrm{~cm} \mathrm{~s}^{-1}$ that is commonly applied in large-scale atmospheric chemistry models. This sensitivity analysis demonstrates that large errors in the description of the wintertime tropospheric ozone budget stem from the uncertain magnitude of ozone deposition rates and the inability to properly parameterize ozone fluxes to snowcovered landscapes.

\section{Introduction}

Human activities have changed the stratospheric and tropospheric ozone budgets and the effects of these changes on terrestrial life are omnipresent. Ozone in the troposphere has been steadily increasing over the past century. Estimates for the concentration increase vary with study region. It is estimated that background ozone has at least doubled since pre-industrial times (Crutzen and Zimmermann, 1991; Staehelin et al., 1994, Wang and Jacob, 1998; Vingarzan 2004); densely populated regions have experienced even larger increases in ozone. The rise in tropospheric ozone is of concern because of health effects on animals, humans and its phytotoxic properties (Lippmann, 1991, Lefohn, 1992; Runeckles and Krupa, 1994). Ozone exposure may result in reduced crop yield, which is a concern for the agricultural economy and world food supply (Herstein et al., 1995). Further increases of tropospheric ozone are anticipated under likely scenarios of increasing regional and global emissions of ozone precursor compounds (Yienger et al., 1999; Vingarzan 2004).

Tropospheric ozone has also been recognized as a significant greenhouse gas. The global anthropogenic radiative forcing of ozone is estimated to be $0.35+1-0.2 \mathrm{~W} \mathrm{~m}^{-2}$,

Published by Copernicus GmbH on behalf of the European Geosciences Union. 
which constitutes $\sim 13 \%$ of all anthropogenic radiative forcing (IPCC, 2001). The contribution of ozone to radiative forcing is particularly large in the polar regions (Mickley et al., 1999) because of the relatively low radiative forcing of water vapor in the cold Arctic and the high albedo over the year-round snowpack, which causes more sunlight to be reflected that can then be intercepted by gases in the atmosphere.

Interestingly, the increase in tropospheric ozone has another, secondary climate feedback effect. The stress and damage to vegetation from ozone exposure has been estimated to reduce the global, biogenic $\mathrm{CO}_{2}$ uptake by $-7.2 \mathrm{PgC}$ per year, which offsets the anthropogenic increase in $\mathrm{CO}_{2}$ uptake by the global biosphere that results from $\mathrm{CO}_{2}$ fertilization, oxidized nitrogen deposition and climate change by an estimated 12\% (Prinn et al., 2005).

The observed changes in ozone and the unique role of ozone in atmospheric chemistry illustrate the importance of improving our understanding of its formation, transport and loss processes. Substantial effort has gone into the development of 3-D models, such as the online chemistry-climate model ECHAM (e.g., Ganzeveld et al., 2002) and offline Chemistry and Transport Models (CTM) such as the Model of Atmospheric Transport and Chemistry-Max Planck Institute for Chemistry (MATCH; Von Kuhlmann et al., 2003), which was applied for the sensitivity analysis in this study. These models incorporate our best understanding of ozone transport from the stratosphere, photochemical formation, and ozone depletion and surface deposition (Ganzeveld and Lelieveld, 1995; Lelieveld and Dentener, 2000).

Tropospheric ozone chemistry in high latitude environments has undergone significant changes from anthropogenic influences. The study of this ozone chemistry has been and continues to be a major research emphasis. Model exercises (for instance Yienger et al., 1999) and airborne field observations, e.g. the Tropospheric Ozone Production about the Spring Equinox (TOPSE) experiment (e.g. Atlas et al., 2003; Wang et al., 2003; Emmons et al., 2003) have revealed new insight into the relative importance of photochemical formation, destruction and transport events. Unique for the polar regions and driven by low water vapor mixing ratios, cold temperatures and low radiation levels, net ozone production occurs down to lower nitrogen oxide (NO) levels (balance point) than in other environments. Because of the large increases in anthropogenic emissions of nitrogen oxides during winter and spring, ozone chemistry has switched from net ozone destruction to net ozone production during those times. This net ozone production has an increasing importance relative to the synoptic transport of ozone from lower latitudes.

\section{Ozone uptake to snow}

Polar regions have experienced significant warming over the past decades, an effect that is largely attributed to climate change and anticipated to further increase in the foreseeable future (ACIA, 2004). The warming of both the polar environment and midlatitude regions is expected to result in further changes in snow cover, surface-atmosphere gas exchange, atmospheric chemistry and climate feedbacks. Recent research has produced increasing evidence that chemical interactions between the atmosphere and falling snow, precipitated snow and snowpack are far more abundant and important to the polar troposphere than previously thought (Domine and Shepson, 2002; Shepson et al., 2003). It has been recognized that processes including the scavenging of gases and particulates by precipitating snow, the dry deposition of atmospheric constituents and the sublimation of water from the snowpack surface lead to the accumulation of snow contaminants in surface snow. Solar irradiance can consequently trigger photochemical reactions of these trace constituents in the snow. These processes result in the formation of gases, including oxidized nitrogen, halogen species, organic compounds and hydrogen peroxide, which subsequently are released into the atmosphere and perturb the gas-phase $\mathrm{HO}_{\mathrm{x}}$ budget and cycling (e.g. Dibb et al., 1998, 2002; Dibb and Arsenault, 2002; Honrath et al., 1999, 2000a, b; Sumner and Shepson, 1999; Zhou et al., 2001; Swanson et al., 2002, 2003).

One of the most dramatic observations initially reported in the 1980s is the sudden and episodic removal of ozone in the Arctic boundary layer (e.g. Bottenheim et al., 1986, 1990; Barrie et al., 1988, 1994; Sturges et al., 1993; Solberg et al. 1996; Barrie and Platt, 1997; Impey et al., 1997). Following the polar sunrise, episodic ozone losses have been routinely observed at places close to the Arctic and Antarctic Oceans. The identified mechanism responsible for ozone depletion is the reaction of ozone with halogens, principally with bromine atoms of marine origin which are formed and released by photochemical heterogeneous ice chemistry (Oltmans et al., 1989; Finlayson-Pitts et al., 1990; Fan and Jacob, 1992; Foster et al., 2001; Bottenheim et al., 2002). This depletion of ozone in the boundary layer has been consistently observed at Northern Hemisphere (NH) polar coastal sites including Barrow, Alert, and Spitzbergen. Continental sites have not exhibited such dramatic ozone declines following the polar sunrise (Helmig et al., 2006a). These contrasting observations re-emphasize that these springtime ozone depletion events are driven by photochemical halogen chemistry, which is linked to elevated halogen levels present in sea-ice and frost flowers in the coastal environment (Hopper et al., 1998; Rankin et al., 2002).

Recent research in Greenland, Antarctica and at a midlatitude site in Michigan has shown that photochemical processes in the sunlit snowpack can also lead to production of substantial amounts of nitrogen oxides $\left(\mathrm{NO}_{\mathrm{x}}=\mathrm{NO}+\mathrm{NO}_{2}\right)$ by photodenitrification (Honrath et al., 1999, 2000a, b; Jones 
et al., 2000; Dibb et al., 2002; Cotter et al., 2003). In a study at Summit, Greenland, Peterson and Honrath (2001) measured diurnal cycles of UV radiation, $\mathrm{NO}_{\mathrm{x}}$ and ozone in interstitial air (the air between snow grains in the snowpack; also referred to as firn air) at $30 \mathrm{~cm}$ depth and compared those measurements with data from above the surface. Ozone and $\mathrm{NO}_{\mathrm{x}}$ in firn air exhibited diurnal cycles with amplitudes of $\sim 10 \mathrm{ppbv}$ and $\sim 350 \mathrm{pptv}$, respectively, and ozone and $\mathrm{NO}_{\mathrm{x}}$ were anti-correlated and directly determined by solar irradiance. Subsequent snowpack measurements at Summit (Helmig et al., 2006b) and South Pole (Helmig, 2003, unpublished results) have further elucidated this process and have shown that ozone in the snowpack is depleted during periods of maximum solar radiation (around solar noon), but does recover during night when solar irradiance drops to below $100 \mathrm{~W} \mathrm{~m}^{-2}$. Similarly, a rapid destruction of ozone was observed in snow chamber experiments (Bottenheim et al., 2002) and firn air profile measurements at Alert (Albert et al., 2002). These data suggest that photochemical formation of NO coincides with and is related to ozone depletion in the snowpack.

The ozone budget above the polar snow is further complicated by photochemical ozone production chemistry. NO, released into the shallow Antarctic surface layer at South Pole, can lead to the buildup of hundreds of pptv ambient air mixing ratios of $\mathrm{NO}_{\mathrm{x}}$ during stable boundary layer conditions (Davis et al., 2001, 2004a, b; Oncley et al., 2004). These enhanced NOx levels drive rather vigorous ozone chemistry. At South Pole, significant ozone enhancements (Crawford et al., 2001; Jones and Wolff, 2003; Helmig et al., 2006c; Oltmans et al., 2006 ${ }^{1}$ ) and boundary layer ozone formation rates of several ppbv per day have been reported (Crawford et al. 2001; Chen et al., 2004). Atmospheric $\mathrm{NO}_{\mathrm{x}}$ mixing ratios and ozone production appear to be highest at South Pole compared to measurements in the Antarctic coastal environment and in the Arctic (Weller et al., 1999; Munger et al., 1999; Jones et al., 1999; Honrath et al., 2002; Yang et al., 2002). Consequently, for South Pole, and likely for vast areas of the Antarctic plateau, the snowpack-atmosphere interface has to be considered a tropospheric ozone source, rather than a sink, during at least part of the Antarctic summer.

The aforementioned and several other gas-exchange experiments have demonstrated the linkage between snowpack photochemical production of several trace gases, their snowpack-atmosphere gas exchange, and resulting changes in atmospheric composition (Hutterli et al., 1999, 2002; Honrath et al., 2000b; Jones et al., 2001; Jacobi et al., 2002; Oncley et al., 2004). These transport processes are driven by diffusion, convection and by ventilation (often referred to as "wind pumping") (Albert and Shultz, 2002). Consequently, the photochemical depletion of ozone in firn air is expected to

\footnotetext{
${ }^{1}$ Oltmans, S., Johnson, B., and Helmig, D.: Episodes of high ozone at South Pole, Atmos. Environ., submitted, 2006.
}

represent a sink mechanism for ozone from above the snow surface.

It can be inferred that the interaction between these processes, e.g. the halogen and oxidized nitrogen chemistry, and physical processes, can lead to both regimes of ozone depletion in interstitial air and in the surface layer, as well as to ozone production above the surface and resulting bidirectional ozone fluxes and flux divergences. These processes are anticipated to be a determining factor for ozone surface deposition and for the tropospheric ozone budget over snow-covered landscapes and within the polar planetary boundary layer. However, published literature on ozone atmosphere-snow fluxes have not explicitly addressed the role of these processes in determining the variability and magnitude of ozone fluxes.

A good body of literature has been generated on atmospheric deposition of ozone over vegetation surfaces, where the ozone deposition velocity commonly increases with stomatal conductance and consequently shows strong diurnal dependencies (Cieslik et al., 2004). The ozone deposition velocity $\left(\mathrm{v}_{d} \mathrm{O} 3\right)$ describes the ability of a surface to remove a gas from the atmosphere regardless of the gas concentration $\left(\mathrm{c}_{\mathrm{O} 3}\right)$, with the actual dry deposition flux $\left(\mathrm{f}_{\mathrm{O} 3}\right)$ being calculated as $\mathrm{f}_{\mathrm{O} 3}=-\mathrm{v}_{d} \mathrm{O} 3 \times \mathrm{c}_{\mathrm{O} 3}$. Average ozone deposition velocities typically range from $0.1-1.0 \mathrm{~cm} \mathrm{~s}^{-1}$ (Padro 1996; Wesely and Hicks, 2000) over different plant canopies.

Relatively little attention has been given to ozone deposition over snow-covered surfaces and reported results show a remarkably wide and poorly understood variability of ozone fluxes. What is commonly referred to as ozone deposition to snow, in reality is the net flux to anything sticking out of the snow, physical uptake of the snow itself, reaction of ozone in interstitial air and losses to the non-gas permeable substrate underneath the snow. As a matter of fact, there is evidence that ozone fluxes may be bi-directional, dependant on the snow properties and environmental conditions. Table 1 summarizes reported ozone flux experiments over snow-covered landscapes. The review of this literature shows that:

- Ozone fluxes in and out of snow vary widely. The ozone exchange velocity was found to be within the range of -3.3 to $1.7 \mathrm{~cm} \mathrm{~s}^{-1}$, however most data are within 0.0 to $0.2 \mathrm{~cm} \mathrm{~s}^{-1}$.

- Significant differences were observed between fresh and aged snow (Galbally and Allison, 1972; Wesely et al., 1981; Stocker et al., 1995): While Galbally and Roy (1980a, b) reported that the ozone deposition velocity increased with snow age, Stocker et al. (1995) found the opposite relationship.

- Several studies report positive fluxes, indicating the release of ozone from the snowpack (Galbally and Allison, 1972; Zeller and Hehn, 1994, 1996; Zeller, 2000). These authors hypothesized that ozone may be temporarily stored in the snow base. However, subsequent 
Table 1. Review of literature with reports on ozone deposition (and emission) fluxes over snow-covered landscapes. References are sorted in order of the publication date. Error bars indicate either the range of observed deposition velocities or reported standard deviations. In cases where upward fluxes were reported, fluxes were converted to "negative deposition rates" in order to allow a comparison with the deposition data.

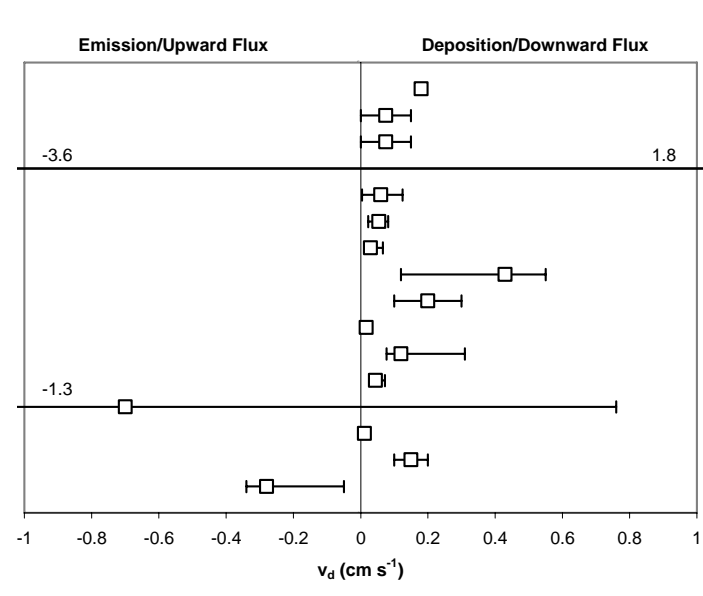

\begin{tabular}{|c|c|c|c|}
\hline Location & $\begin{array}{l}\text { Landscape } \\
\text { Type }\end{array}$ & Comments & Reference \\
\hline New Mexico, U.S. & $1 \mathrm{~cm}$ snow depth & Measued decay rate of ozone in a chamber experiment & Aldaz, 1969 \\
\hline Mawson, Antarctica & Glacial snow field & Data is estimated upper limit & Galbally \& Allison, 1972 \\
\hline Mt Buller, Australia & $1.3 \mathrm{~m}$ Snow Depth & Old snow, data is upper limit of $v_{d}$ & Galbally \& Allison, 1972 \\
\hline Mt Buller, Australia & $1.3 \mathrm{~m}$ snow depth & New to one day-old snow, upward flux over fresh snow & Galbally \& Allison, 1972 \\
\hline Australia & $1.3 \mathrm{~m}$ snow depth & Deposition velocity increased with snow age. & Galbally and Roy, 1980a,b \\
\hline Illinois, U.S. & Plowed field & Fresh Snow & Wesely et al., 1981 \\
\hline Illinois, U.S. & Plowed field & Aged Snow & Wesely et al., 1981 \\
\hline Lancaster/England & Grass field & & Colbeck \& Harrison, 1985 \\
\hline Canada & Deciduous forest & & Padro et al. 1992, Padro 1993 \\
\hline Wyoming, U.S. & Coniferous forest & Downward flux, error bars are standard deviation & Zeller and Hehn, 1995 \\
\hline Colorado, U.S. & Grassland & Fresh snow & Stocker et al., 1995 \\
\hline Colorado, U.S. & Grassland & Aged snow & Stocker et al., 1995 \\
\hline Wyoming, U.S. & Coniferous forest & Consistent upwards ozone fluxes observed. & Zeller \& Hehn, 1996 \\
\hline Camp Narwahl & Ice camp on sea ice & Data for ozone depletion events (Polar Sunrise) & Gong et al., 1997 \\
\hline Alert, Canada & Ice camp on sea ice & Estimate for surface depositon during ozone depletion events & Hopper et al., 1998 \\
\hline Wyoming, U.S. & Coniferous forest & Upwards ozone fluxes (mean $0.2 \mu \mathrm{g} \mathrm{m}^{-2} \mathrm{~s}^{-1}$ ) & Zeller, 2000 \\
\hline
\end{tabular}

during polar sunrise ozone depletion events, do not reflect the typical, year-round ozone loss rates over snow-covered sea-ice.

It is obvious that data representing ozone fluxes over the polar icecaps, under conditions of year-round snow accumulation, and year-round scavenging and deposition of trace gases to snow are lacking. Particularly the condition of extended snow accumulation in the absence of light during the polar winter, followed by exposure to the high solar irradiance in the spring-summer season, is not reflected by these studies. Therefore, it is highly uncertain how the published literature relates to polar conditions. In summary, with the current body of data many important questions on the ozone dynamics and its variability over snow-covered landscapes can not be conclusively assessed. Important, unanswered questions are:

- What are the seasonal and annual ozone fluxes over snow-covered landscapes? When is snow a sink or source for tropospheric ozone?

- What are the chemical and meteorological controls of ozone fluxes into the firn/snowpack?

- How does the ozone deposition rate depend on solar irradiance? What is the linkage between ozone deposition and photochemical processes in the snow?

- What is the geographical distribution in ozone fluxes?

- Is ozone chemically produced and released at the snowpack-atmosphere interface or produced in the atmospheric surface layer? Under which conditions does this ozone production occur? 
- What role does the substrate under the snowpack play, e.g. how are ozone-snowpack fluxes influenced by soil, rocks, vegetation or glacial ice under the permeable snowpack layer?

This deficiency constrains our understanding of the ozone budget in the polar surface and boundary layer. Ozone deposition rates used in the MOZART (Model for Ozone and Related Chemical Tracers; Brasseur et al., 1998) and IMAGES (Intermediate Model for the Annual and Global Evolution of Species, Muller and Brasseur, 1995) models for snow-covered, southern and northern latitudes $>75^{\circ}$ are in the range of $0.001 \mathrm{~cm} \mathrm{~s}^{-1}$ for winter, $0.02 \mathrm{~cm} \mathrm{~s}^{-1}$ for nighttime summer and $0.1 \mathrm{~cm} \mathrm{~s}^{-1}$ for daytime summer conditions (J. F. Lamarque, NCAR, 2004, personal communication). In MATCH the $\mathrm{O}_{3}$ dry deposition velocity is calculated from the seasonal changes in surface cover, plant-stomatal uptake and turbulence and diffusion. These parameters typically result in snow/ice dry deposition velocity ranges between 0.045-0.050 $\mathrm{cm} \mathrm{s}^{-1}$ (Ganzeveld and Lelieveld, 1995; Ganzeveld et al., 1998). These values do not consider the spatial and temporal variability in ozone deposition related to snow-photochemical influences but solely rely on seasonal and diurnal changes in the turbulent transport and quasilaminar resistances that complement constant surface uptake resistances. The latter reflect the removal efficiency for the particular snowpack chemical conditions.

The high variability and inconsistency in the ozone flux data published in the literature and the complexity of chemical processes in the snow and in the surface layer raise the question as to which published data would be the most appropriate for a description of the role of surface exchanges in large-scale polar tropospheric ozone chemistry in the models. Year-round ozone flux measurements in a variety of polar locations with different characteristics would be desirable, but such measurements would be an extremely challenging experiment under the harsh conditions in the remote polar environments. Therefore, the sensitivity analyses that are described in the following part of this manuscript were performed with the goal of narrowing down the range for representative ozone uptake rates to be recommended for use in atmospheric models. In addition, this analysis was meant to characterize the spatial differences in the influence of ozone snowpack-atmosphere fluxes on atmospheric ozone levels in the polar regions.

\section{Sensitivity analyses}

The sensitivity of tropospheric ozone on the deposition to snow-covered landscapes was studied by comparing model results from different deposition scenarios and by performing spatial and temporal comparisons between surface ozone measurements and model calculations. For the spatial comparison of the NH ozone distribution, data and model outputs for the month of January were investigated. January was chosen because a) a relatively higher sensitivity was expected due to the relatively large snow cover extend during the winter months and b) photochemical processes are relatively weak at this time. As such the analyses aim at identifying the role of the physical (dark) surface ozone deposition process in the ozone budget with a minimum role of snowpack photochemistry in terms of its contribution to the temporal and spatial variability in ozone fluxes. Consequently, this approach allows a more straightforward comparison between ambient data and the model, which at the current state does not include snowpack and surface/boundary layer halogen and oxidized nitrogen chemistry.

The model studies were done with MATCH using a T42 horizontal resolution, corresponding to a grid size of $\sim 2.8$ degrees, and 19 vertical layers in a hybrid $\sigma$-p coordinate system extending to about $30 \mathrm{~km}$ altitude, and a time step of $20 \mathrm{~min}$. The model is driven using NCEP (National Center for Environmental Prediction) re-analyses (Kalnay et al., 1996) at a temporal resolution of $6 \mathrm{~h}$. The model considers advective, turbulent and convective tracer transport and includes the gas-phase chemistry of methane $\left(\mathrm{CH}_{4}\right)$ and NonMethane Hydrocarbons (NMHC, e.g. isoprene) including a selection of NMHC oxidation products such as formaldehyde, higher aldehydes and acetone. Emissions include anthropogenic and biomass burning emissions of $\mathrm{NO}_{\mathrm{x}}, \mathrm{CO}$, and NMHC based on Dentener et al. (2005). Dry deposition processes are described using the "big leaf" resistance approach considering turbulent transport to the surface, stomatal uptake, and different uptake rates for the ocean, snow, bare soil and wet surfaces (vegetation and soil wetted due to rainfall interception and dewfall), expressed on a sub-grid scale by selected or explicitly resolved uptake resistances (Ganzeveld and Lelieveld, 1995; Ganzeveld et al., 1998). The snow cover fraction in the MATCH simulations presented here is prescribed based on a simulation with the general circulation model ECHAM5 (Roeckner et al., 2003) using the Atmospheric Model Intercomparison Project (AMIP) (Gates et al., 1998) sea surface temperatures for the year 1987 (Taylor et al., 2000). The sea ice fraction is prescribed based on a climatology of sea ice observations. The model was initialised with fields from a climatological run of MATCH (von Kuhlmann et al., 2003) starting in October 1999 and allowing the model to spin up for three months presenting hourly ozone outputs for the year 2000 and monthly mean results for January 2000.

\section{Ambient ozone observations}

Public data with continuous (hourly) ozone measurements (retrieved from the WMO archive http://gaw.kishou.go.jp/ wdcgg.html) from stations at $>60^{\circ} \mathrm{N}$ Ahtari (Finland), Barrow (Alaska, USA), Haimaey (Iceland), Oulanka (Finland), Pallas-Sammaltunturi (Finland), Vindeln (Sweden), Summit and Zeppelinfjellet (Spitzbergen, Norway) were analyzed 
Table 2. Mean January surface layer ozone mixing ratio at selected Arctic monitoring stations. Data for Ahtari, Barrow, Haimey, Oulanka, Pallas, Summit, Vindeln and Zeppelinfjellet are from continuous surface monitoring, other data are mean ozone in the lowest $100 \mathrm{~m}$ from ozone sonde launches. These data are compared to results obtained with the MATCH model at four different ozone deposition velocities using year 2000 meteorological data fields.

\begin{tabular}{|c|c|c|c|c|c|c|c|c|c|c|c|c|c|c|}
\hline \multirow[t]{2}{*}{ Site } & \multirow[t]{2}{*}{ Latitude } & \multirow[t]{2}{*}{ Longitude } & \multirow{2}{*}{$\begin{array}{c}\text { Elevation } \\
\text { (m asl) }\end{array}$} & \multirow[t]{2}{*}{ Year } & \multirow{2}{*}{$\begin{array}{c}\text { January Ozone } \\
\text { Observation (ppbv) } \\
\text { Mean } \pm \text { Std Dev }\end{array}$} & \multirow{2}{*}{$\begin{array}{c}\text { Number of } \\
\text { Measure- } \\
\text { ments }\end{array}$} & \multicolumn{4}{|c|}{ MATCH Mean January 2000 Ozone (ppbv, \pm Std Dev) } & \multicolumn{4}{|c|}{ Deviation between Observations and MATCH (ppbv) } \\
\hline & & & & & & & $\begin{array}{l}\mathrm{r}_{\mathrm{s}}=1000 \mathrm{sm}^{-1} \\
\mathrm{v}_{\mathrm{v}}=0.1 \mathrm{~cm} \mathrm{~s} \mathrm{~s}^{-1}\end{array}$ & $\begin{array}{l}\mathrm{r}_{\mathrm{r}}=2000 \mathrm{sm}^{-1} \\
\mathrm{v}_{\mathrm{e}}=0.05 \mathrm{~cm} \mathrm{~s}^{-1}\end{array}$ & $\begin{array}{l}\mathrm{r}_{\mathrm{s}}=10000 \mathrm{~s} \mathrm{~m}^{-1} \\
\mathrm{v}_{\mathrm{a}}=0.01 \mathrm{cms}^{-1}\end{array}$ & $\begin{array}{l}\mathrm{r}_{\mathrm{r}} \gg 10000 \mathrm{~s} \mathrm{~m}^{-1} \\
\mathrm{v}_{\mathrm{v}}=0.0 .0 \mathrm{~cm} \mathrm{~s}^{-1}\end{array}$ & $\begin{array}{l}\mathrm{r}_{\mathrm{z}}=1000 \mathrm{~s} \mathrm{~m}^{-1} \\
\mathrm{v}_{\mathrm{v}}=0.1 \mathrm{~cm} \mathrm{~s} \mathrm{~s}^{-1}\end{array}$ & $\begin{array}{l}\mathrm{r}_{\mathrm{r}}=2000 \mathrm{sm}^{-1} \\
\mathrm{v}_{0}=0.05 \mathrm{~cm} \mathrm{~s}^{-1}\end{array}$ & $\begin{array}{l}\mathrm{r}_{\mathrm{r}}=10000 \mathrm{sm}^{-1} \\
\mathrm{v}_{\mathrm{a}}=0.01 \mathrm{~cm} \mathrm{~s}^{-1}\end{array}$ & $\begin{array}{l}\mathrm{r}_{\mathrm{r}}>10000 \mathrm{sm}^{-1} \\
\mathrm{v}_{\mathrm{d}}=0.0 .0 \mathrm{~cm} \mathrm{~s}^{-1}\end{array}$ \\
\hline Ahtari & $6235^{\prime} \mathrm{N}$ & $2412^{\prime} \mathrm{E}$ & 180 & 2002 & $26.1 \pm 6.1$ & hourly & $14.9 \pm 6.3$ & $18.0 \pm 6.5$ & $22.3 \pm 7.0$ & $23.7 \pm 7.4$ & 11.2 & 8.1 & 3.8 & 2.4 \\
\hline Alert & $8227^{\prime} \mathrm{N}$ & $6231^{\prime} \mathrm{W}$ & 10 & $2000-2004$ & $32.7 \pm 4.2$ & 31 & $16.6 \pm 4.0$ & $22.2 \pm 3.9$ & $31.3 \pm 3.4$ & $35.4 \pm 3.3$ & 16.1 & 10.5 & 1.4 & -2.7 \\
\hline Barrow & $7119^{\prime} \mathrm{N}$ & $15635^{\prime} \mathrm{W}$ & 8 & 2000 & $27.4 \pm 2.9$ & hourly & $11.2 \pm 4.5$ & $16.4 \pm 4.3$ & $26.8 \pm 3.2$ & $31.9 \pm 3.2^{*}$ & 16.2 & 11.1 & 0.6 & -4.5 \\
\hline Bear Island & $7431^{\prime} \mathrm{N}$ & $1910^{\prime} \mathrm{E}$ & 10 & $1994-1997$ & $30.3 \pm 4.5$ & 14 & $23.7 \pm 5.1$ & $26.3 \pm 5.0$ & $30.1 \pm 4.9$ & $31.5 \pm 5.2$ & 6.6 & 4.0 & 0.2 & -1.2 \\
\hline Eureka & $7959^{\prime} \mathrm{N}$ & $8556^{\prime} \mathrm{W}$ & 10 & 2000 & $31.6 \pm 4.0$ & 56 & $14 \pm 4.7$ & $19.9 \pm 4.6$ & $30.3 \pm 3.5$ & $35.2 \pm 3.0$ & 17.6 & 11.7 & 1.3 & -3.6 \\
\hline Haimaey/Westman Isl. & $6324^{\prime} \mathrm{N}$ & $2017^{\prime} \mathrm{W}$ & 100 & 2004 & $40.7 \pm 3.1$ & hourly & $31.4 \pm 4.6$ & $33.0 \pm 3.9$ & $35.3 \pm 3.2$ & $36.2 \pm 3.0$ & 9.3 & 7.7 & 5.4 & 4.5 \\
\hline Keflavik & $6359^{\prime} \mathrm{N}$ & $2236^{\prime} \mathrm{W}$ & 52 & $1994-1999$ & $34.9 \pm 3.6$ & 20 & $31.8 \pm 4.7$ & $33.5 \pm 4.0$ & $35.8 \pm 3.2$ & $36.8 \pm 3.1$ & 3.1 & 1.4 & -0.9 & -1.8 \\
\hline Oulanka & $6619^{\prime} \mathrm{N}$ & $2924^{\prime} \mathrm{E}$ & 310 & 2001 & $25.8 \pm 7.5$ & hourly & $16.1 \pm 5.2$ & $19.6 \pm 5.6$ & $24.4 \pm 6.5$ & $25.9 \pm 7.2$ & 9.7 & 6.2 & 1.4 & -0.1 \\
\hline Pallas-Sammaltunturi & $6758^{\prime} \mathrm{N}$ & $2407^{\prime} \mathrm{E}$ & 565 & 2000 & $32.8 \pm 5.7$ & hourly & $18.4 \pm 5.8$ & $22.2 \pm 6.1$ & $27.5 \pm 6.7^{*}$ & $29.3 \pm 7.3$ & 14.4 & 10.6 & 5.3 & 3.5 \\
\hline Resolute & $7441^{\prime} \mathrm{N}$ & $9442^{\prime} \mathrm{W}$ & 30 & 1998 - 2003 & $30.5 \pm 6.1$ & 20 & $12.4 \pm 5.8$ & $17.9 \pm 5.5$ & $28.4 \pm 3.7$ & $33.4 \pm 3.0$ & 18.1 & 12.6 & 2.1 & -2.9 \\
\hline Salekhar & $6631^{\prime} \mathrm{N}$ & $6636^{\prime} \mathrm{E}$ & 16 & 1998 & $24.4 \pm 6.3$ & 6 & $13.3 \pm 7.6$ & $17.6 \pm 8.0$ & $24.3 \pm 7.7$ & $26.7 \pm 7.5$ & 11.0 & 6.7 & 0.0 & -2.4 \\
\hline Scoresbysund & $7048^{\prime} \mathrm{N}$ & $2197^{\prime} \mathrm{W}$ & 69 & $1998-2001$ & $37.9 \pm 3.2$ & 26 & $22.7 \pm 4.3$ & $27.4 \pm 4.5$ & $33.4 \pm 4.7$ & $35.4 \pm 4.9$ & 15.2 & 10.5 & 4.5 & 2.5 \\
\hline Sodankyla & $6724^{\prime} \mathrm{N}$ & $2636^{\prime} \mathrm{E}$ & 179 & $1995-1998$ & $29.0 \pm 7.1$ & 38 & $18.4 \pm 5.8$ & $22.2 \pm 6.1$ & $27.5 \pm 6.7$ & $29.3 \pm 7.3$ & 10.6 & 6.8 & 1.5 & -0.3 \\
\hline Sondrestrom & $6659^{\prime} \mathrm{N}$ & $5058^{\prime} \mathrm{W}$ & 350 & 1995,1997 & $35.8 \pm 3.4$ & 5 & $23.2 \pm 6.1$ & $27.5 \pm 5.3$ & $33.7 \pm 4.0$ & $36.2 \pm 3.5$ & 12.6 & 8.3 & 2.1 & -0.4 \\
\hline Summit & $7235^{\prime} \mathrm{N}$ & $3829^{\prime} \mathrm{W}$ & 3208 & 2004 & $45.3 \pm 3.0$ & hourly & $27.3 \pm 6.8$ & $30.9 \pm 6.2$ & $35.6 \pm 5.3$ & $37.4 \pm 5.1$ & 18.0 & 14.4 & 9.7 & 7.9 \\
\hline Thule & $7631^{\prime} \mathrm{N}$ & $6850^{\prime} \mathrm{W}$ & 59 & $1996-2001$ & $32.9 \pm 5.9$ & 23 & $19.3 \pm 5.2$ & $25.3 \pm 5.0$ & $33.8 \pm 4.2$ & $37.1 \pm 3.8$ & 13.6 & 7.6 & -1.0 & -4.2 \\
\hline Vindeln & $6415^{\prime} \mathrm{N}$ & $1946^{\prime} \mathrm{E}$ & 271 & 2000 & $31.6 \pm 6.0$ & hourly & $21.7 \pm 7.1$ & $25.0 \pm 7.4$ & $29.3 \pm 7.9^{*}$ & $30.8 \pm 8.4$ & 9.9 & 6.6 & 2.3 & 0.8 \\
\hline Zeppelinfjellet/Ny Al. & $7854^{\prime} \mathrm{N}$ & $1153^{\prime} \mathrm{E}$ & 475 & 2000 & $32.7 \pm 3.1$ & hourly & $20.7 \pm 5.4$ & $24.1 \pm 4.9$ & $29.4 \pm 4.5^{*}$ & $31.5 \pm 4.8$ & 12.0 & 8.6 & 3.3 & 1.2 \\
\hline & & & & & & & & & & $\begin{array}{l}\text { Median: } \\
\text { Average: }\end{array}$ & $\begin{array}{l}12.6 \\
12.6\end{array}$ & $\begin{array}{l}8.3 \\
8.5\end{array}$ & $\begin{array}{l}1.5 \\
2.3\end{array}$ & $\begin{array}{l}-0.4 \\
-0.2\end{array}$ \\
\hline
\end{tabular}

for this study. Station locations are shown in Fig. 1. Besides these continuous measurements, ozone sonde data from Resolute (Canada), Eureka (Canada), Alert (Canada), Thule (Greenland), Sondrestrom (Greenland), Scoresbysund (Greenland), Keflavik (Iceland), Bear Island (Norway), Sodankyla (Finland) and Salekhard (Russia) were included. Locations of these sites are also shown in Fig. 1, coordinates are given in Table 2. These ozone sonde data were obtained from the World Ozone and Ultraviolet Data Center archive (http://www.woudc.org/) and the NADIR data centre (http://www.nilu.no/projects/nadir/). Most of these ozone sonde data are not from regular, continuous ozone sonde launches but from selected experiments that were performed in the framework of stratospheric research campaigns. As many profiles as available for the month of January during the 1994-2005 period were considered (Table 2). These sonde data were critically evaluated for completeness and quality of observations obtained during the launch phase $(\sim$ first $100 \mathrm{~m}$ ). Typically, 1-6 data points are recorded during this time. These data points were averaged for an estimate of the mean, January surface layer ozone mixing ratio. A few profiles with very rapid changes of ozone in the first $100 \mathrm{~m}$ were excluded. We suspected these rapid changes to stem from insufficient equilibration of the ozone sonde with ambient air conditions prior to the balloon launch (chemical ozone gradients of this magnitude appear highly unlikely during the month of January since photochemical ozone depletion processes in these Arctic regions typically do not occur until mid to late February). The mean January ozone mixing ratio for Alert (31.8 ppb for the year 2000) derived from the sonde data analysis does compare well with January continuous monitoring ozone data reported by Anlauf et al. (1994), which were 26-33 ppbv (range of median ozone in eight wind sectors) during January 1992. Albeit the sonde data are somewhat lower than the mean 1992-2003 January median of $35.2 \mathrm{ppbv}$ (Helmig et al., 2006a). Continuous measurements at three Greenland sites during 1994-1996 were reported by Rasmussen et al. (1997). The range of their data was 35-42 ppbv at Thule (1996), 26-32 ppbv (1995) and 3237 ppbv (1996) at Scoresbysund and 33-43 ppbv (1996) at Sondrestrom. The results from our sonde data analyses agree reasonably with these observations, except for Thule, where the median sonde data $(32.9 \mathrm{ppbv})$ are below the range of the January 1996 continuous data.

Even though these stations are scattered between $62-83^{\circ} \mathrm{N}$ and over a wide surface area, a remarkably narrow range was found for January surface ozone at these locations. Except for the Greenland and Iceland sites, most of the median ozone surface data fall between 26-33 ppbv. At Summit, Scoresbysund and Haimaey, January surface ozone is significantly higher $(45,38,41 \mathrm{ppbv}$, respectively). Ozone at Summit has previously been noted to be higher than at other Arctic locations. A combination of conditions was identified to influence surface ozone at Summit. Most importantly, the enhanced ozone at Summit was found to reflect $\mathrm{NH}$ ozone at Summit's altitude of $3208 \mathrm{~m}$ a.s.l., stratospheric 
transport events are contributing to surface ozone at Summit, in particular during the late spring and early summer season, and Summit was found to occasionally receive polluted air with enhanced ozone from lower latitude, continental regions (Helmig et al., 2006d). Scoresbysund, located on the east coast of Greenland, and Haimaey may possibly be influenced by a similar effect, receiving air from downslope transport with enhanced ozone levels from the Greenland ice shield.

\section{Modeling results}

Results from the model runs are shown in Figs. 2-7. First, Figs. $2 \mathrm{a}$ and $\mathrm{b}$ show an evaluation of the January average snow and sea-ice cover fraction (range of 0-1) that was applied in MATCH, based on simulations with ECHAM5. The calculated snow and sea-ice cover simulations from ECHAM5 represent the mean of January 1987 conditions. These data, for a qualitative comparison are shown side-byside with satellite-derived snow and sea-ice cover for 15 January 2004. It can be inferred that the modeled snow and sea-ice cover generally resembles the observed data well except for some isolated regions, e.g., western USA, where the model snow cover appears to be smaller compared to observations, whereas in northeast China the model snow cover is larger compared to the observations. More detailed analysis of possible explanations for these biases such as the applied model resolution relevant to the representation of orography or different reference years (observations were from one day in 2004, model calculations were a one-month average based on 1987 data) is beyond the scope of this study; an in-depth description and evaluation of ECHAM snow cover parameterization has been carried out in the context of two previous publications (Roesch et al., 2001; Roesch and Roeckner, 2006).

Figure 3 shows the simulated bulk $\mathrm{O}_{3}$ dry deposition velocity north of $30^{\circ} \mathrm{N}$ that results from a $\mathrm{v}_{d 03, \text { snow }}=0.05 \mathrm{~cm} \mathrm{~s}^{-1}$ calculation. Values of $\mathrm{v}_{d \mathrm{O}}$ around $0.05 \mathrm{~cm} \mathrm{~s}^{-1}$ over land mostly resemble the snow-cover distribution whereas larger deposition velocities $>0.2 \mathrm{~cm} \mathrm{~s}^{-1}$ reflect removal by dry and wet bare soil and vegetation, although stomatal uptake is limited by the low radiation conditions for the $\mathrm{NH}$ winter. In the default set-up of MATCH's dry deposition scheme the $\mathrm{O}_{3}$ dry deposition velocity over snow-covered surfaces (including glaciers) and sea ice reflects a selected constant snow-ice uptake resistance $\left(\mathrm{r}_{\text {snow-ice }}\right)$ of $2000 \mathrm{~s} \mathrm{~m}^{-1}$, which is significantly larger than the explicitly calculated aerodynamic $\left(\mathrm{r}_{a}\right)$ and quasilaminar boundary layer $\left(\mathrm{r}_{b}\right)$ resistance. This explains the small magnitude, $<0.05 \mathrm{~cm} \mathrm{~s}^{-1}\left(1 / 2000 \mathrm{~s} \mathrm{~m}^{-1}\right)$ as well as the small variability in the simulated ozone dry deposition velocity, which is due to only a small contribution by the spatial and temporal variability in the simulated turbulence and diffusion. Over the ocean, sea-ice cover is not distinguishable in

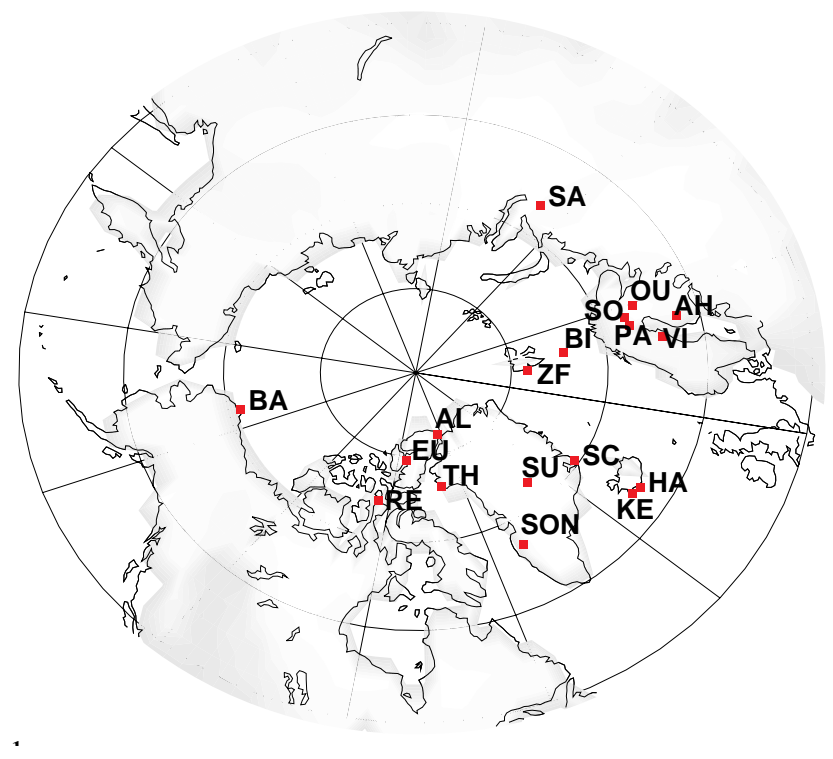

Fig. 1. Location of research sites that were included in the comparison of observational data with the model calculations. Used station abbreviations are AH, Ahtari; AL, Alert; BA, Barrow; BI, Bear Island; EU, Eureka; HA, Haimaey; KE, Keflavik; OU, Oulanka; PA, Pallas-Sammaltunturi; RE, Resolute; SA, Salekhar; SC, Scoresbysund; SO, Sodankyla; SON, Sondrestrom; SU, Summit; TH, Thule; VI, Vindeln and ZF, Zeppelinfjellet. Site coordinates are given in Table 2.

the spatial distribution of $\mathrm{v}_{d \mathrm{O}}$ since the snow-ice and ocean surface resistance, which control $\mathrm{v}_{d \mathrm{O}}$, are similar.

Surface layer ozone mixing ratios are not solely driven by surface deposition, but will also depend on advection, photochemical ozone production and depletion as well as by transport from the stratosphere. All of these parameters have temporal and geographical dependencies. The distribution and resulting mean January ozone mixing ratio is shown in Fig. 4. Minimum $\mathrm{O}_{3}$ surface layer mixing ratios of $10-15 \mathrm{ppbv}$ in anthropogenic source regions such as Europe, Russia, China and the east coast of the U.S. are due to the anthropogenic emissions of NO in the stable boundary layer thereby titrating ozone. The mixing ratios over snow and sea-ice are generally around $15-20$ ppbv except for elevated locations such as Greenland, where January mean mixing ratios of up to $35 \mathrm{ppbv}$ are simulated.

The sensitivity of surface-layer ozone to ozone deposition to snow was investigated by comparing the MATCH results from the default ozone deposition velocity of $\mathrm{v}_{d \mathrm{O} 3} \leq 0.05 \mathrm{~cm} \mathrm{~s}^{-1}$ (Fig. 4, hereafter referred to

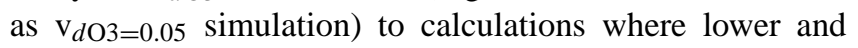
higher ozone deposition velocities of $\mathrm{v}_{d \mathrm{O} 3}=0.0 ; \leq 0.01$ $\left(\mathrm{r}_{\text {snow-ice }}=10000 \mathrm{~s} \mathrm{~m}^{-1}, \quad \mathrm{v}_{d \mathrm{O} 3=0.01}\right) \quad$ and $\leq 0.10 \mathrm{~cm} \mathrm{~s}^{-1}$ $\left(\mathrm{r}_{\text {snow-ice }}=1000 \mathrm{~s} \mathrm{~m}^{-1}, \mathrm{v}_{d \mathrm{O} 3=0.1}\right)$ were applied. Besides this change in ozone deposition velocity, all other model parameters were kept the same. These applied ozone 

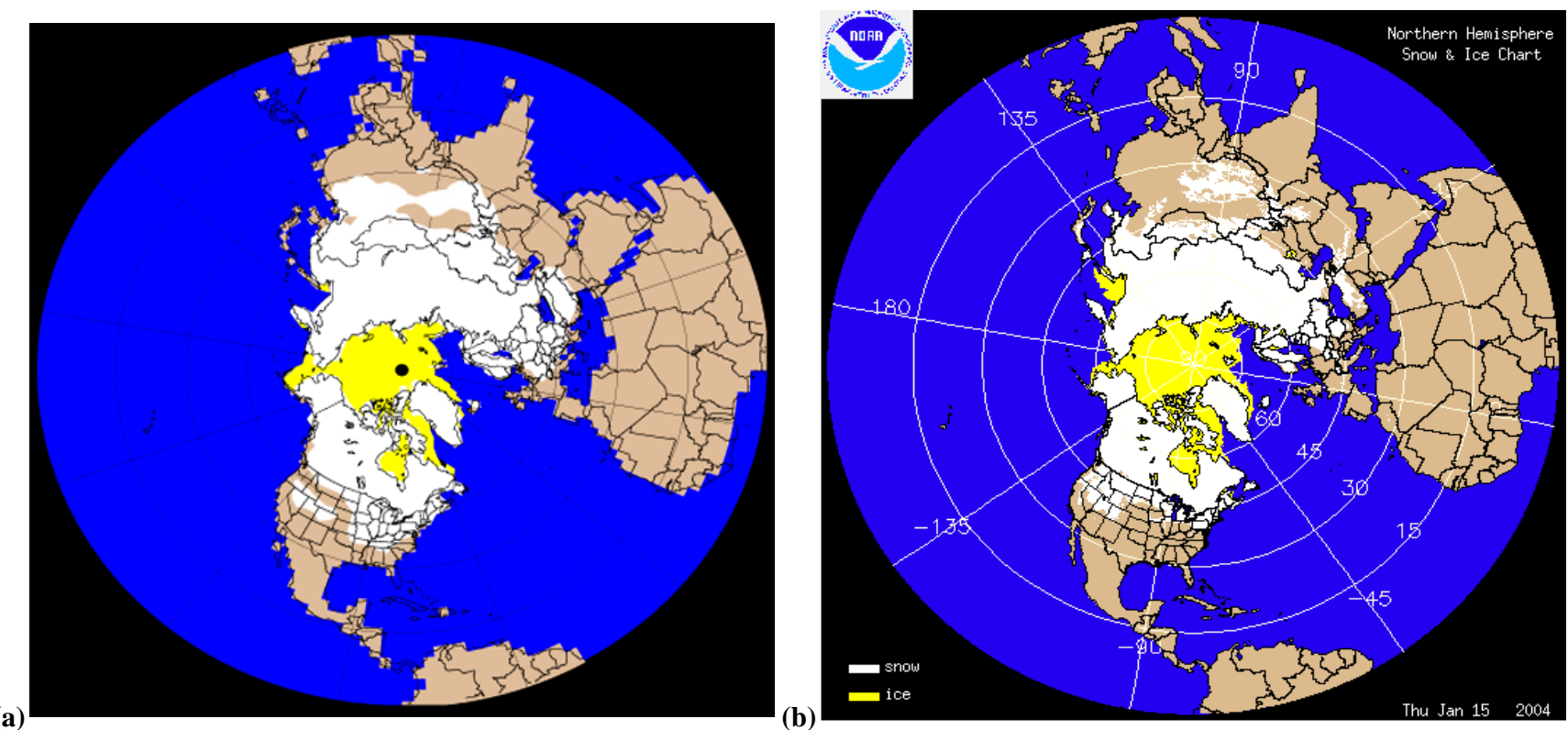

Fig. 2. Mean January snow and sea-ice cover fraction output from MATCH (left) in comparison with satellite-derived snow and sea-ice cover observations for the Northern Hemisphere. The observational data are from 15 January 2004 (source http://www.ssd.noaa.gov/PS/SNOW/).

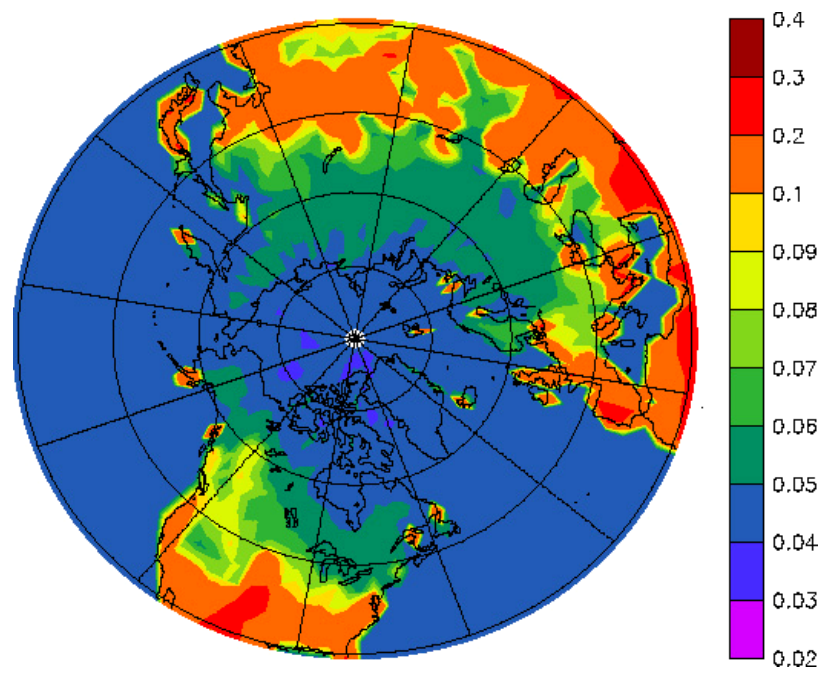

Fig. 3. January bulk ozone deposition velocity $\left(\mathrm{cm} \mathrm{s}^{-1}\right)$ calculated using $\mathrm{r}_{\text {snow-ice }}=2000 \mathrm{~s} \mathrm{~m}^{-1}\left(\mathrm{v}_{d} \leq 0.05 \mathrm{~cm} \mathrm{~s}^{-1}\right)$.

deposition velocity values are well within and far from the extremes of any in the reported literature.

The relative difference in the spatial distribution of surface-layer ozone for the month of January between the $\mathrm{v}_{d \mathrm{O} 3=0.05}$ and the $\mathrm{v}_{d \mathrm{O} 3=0.01}$ simulation is shown in Fig. 5a (relative to the $\mathrm{v}_{d 03}=0.05$ simulation). Figure $5 \mathrm{~b}$ shows the relative difference for $65^{\circ} \mathrm{N}$ as a function of height up to $850 \mathrm{hPa}(\sim 1500 \mathrm{~m})$. It is clearly seen that differences are mostly limited to the atmosphere over the areas with

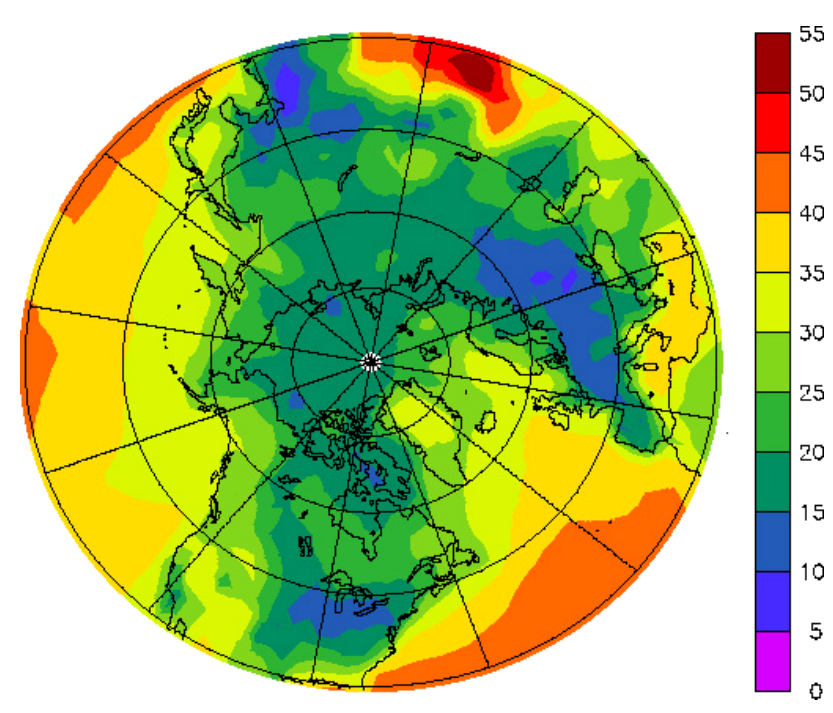

Fig. 4. Mean, January surface layer ozone (in ppbv) calculated with MATCH using the snow cover and deposition data in Figs. 2 and 3.

snow and sea-ice with maximum relative differences up to $80 \%$ north of Alaska and Canada coinciding with those $\mathrm{Ar}$ tic regions where minimum concentrations are simulated as shown in Fig. 4. On average, differences north of $60^{\circ} \mathrm{N}$ are generally larger then $20-30 \%$. There are significant relative increases $( \pm 25 \%)$ in $\mathrm{O}_{3}$ concentrations up to an altitude of $1000-1500 \mathrm{~m}$ over those locations with maximum relative changes in surface ozone. Over Greenland, where the highest high-latitude surface layer mixing ratios of $40-45 \mathrm{ppbv}$ 

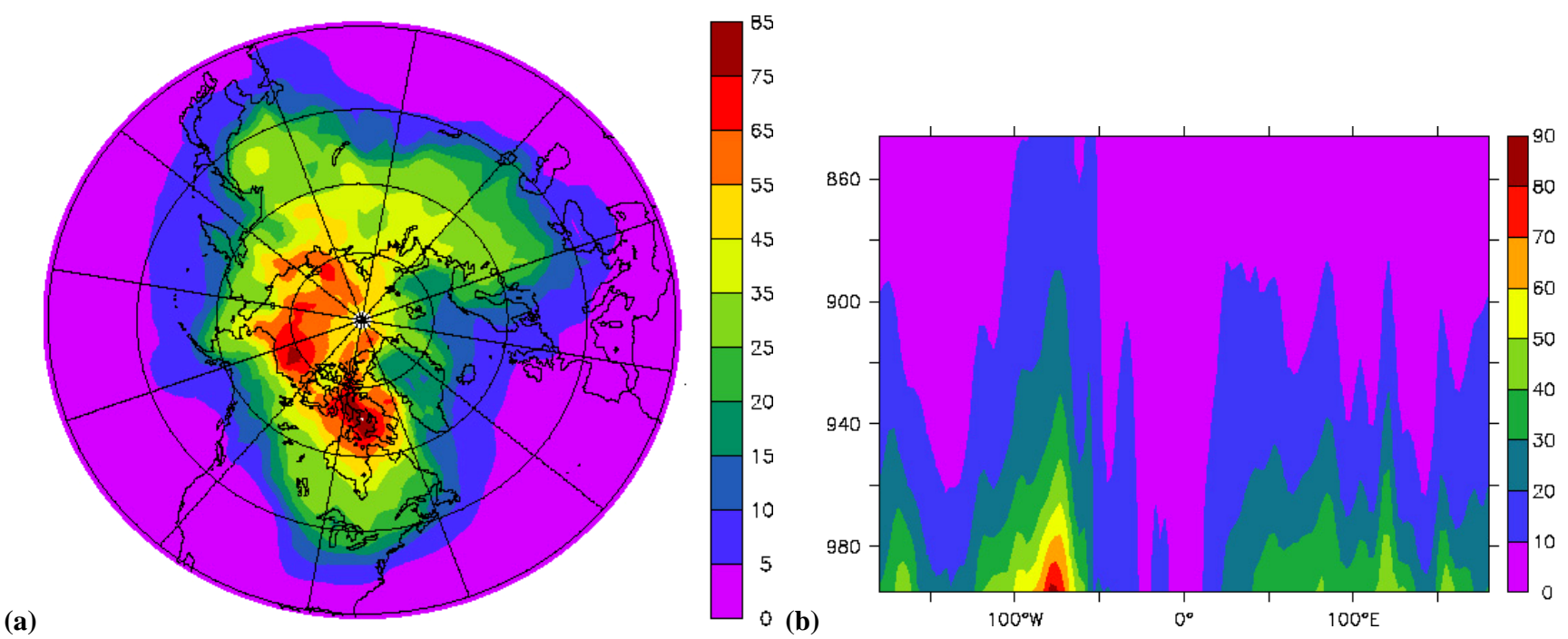

Fig. 5. Relative increase in the mean January Northern Hemisphere surface ozone mixing ratio (\%) (a) and up to $850 \mathrm{hPa}$ along $65 \mathrm{~N}$ (b) resulting from the decrease of the default ozone deposition velocity of $\mathrm{v}_{d} \mathrm{O} 3 \leq 0.05 \mathrm{~cm} \mathrm{~s}^{-1}$ to a lower value of $\mathrm{v}_{d} \mathrm{O} 3 \leq 0.01 \mathrm{~cm} \mathrm{~s}-1$ over snow covered landscapes and sea-ice.

occur, an increase of about $7 \mathrm{ppbv}$ is simulated.

\section{Comparison of observations and MATCH results}

Comparison of observations and MATCH model results were done using several approaches. The spatial distribution of surface level ozone was compared for the month of January. A comparison of the field data with the model computation is presented in Table 2. An evaluation of these data was attempted by comparing the deviations between the four model scenarios and the ambient measurement data. The median and average differences between observations and model results for all stations for the four tested ozone deposition velocity cases is included at the bottom of Table 2 .

The decrease of the ozone deposition velocity reduces the loss rate of ozone to the snow surface. This lower ozone sink results in increased levels of ozone in the surface layer. This relationship is clearly evident in the MATCH results. The sensitivity towards this change varies widely between the investigated sites, reflecting the differing importance of transport, and boundary layer and surface layer chemical and physical processes at these sites (see further discussion below). Average increases in surface ozone are 5, 12, and 15 ppbv, respectively, when the ozone deposition rate is reduced from $0.10 \mathrm{~cm} \mathrm{~s}^{-1}$ to $0.05,0.01$ and $0.00 \mathrm{~cm} \mathrm{~s}^{-1}$, respectively. As mentioned above, even though this is a large relative change in the ozone deposition velocity, on an absolute scale, these deposition velocities are rather small, since in most other environments ozone deposition velocities in the range of $0.5-2 \mathrm{~cm} \mathrm{~s}^{-1}$ are common. But given the lack or weakness of other chemical and physical ozone sources and sinks during January in high Northern Latitudes, the importance of the surface loss to the ozone budget becomes clearly evident from these calculations. Note that this sensitivity of the atmospheric ozone concentrations to snow dry deposition has also been reproduced with a second model, the online chemistry-climate model ECHAM5-MESSy (unpublished data), indicating the robustness of the results presented here from the MATCH simulations.

While results for individual sites vary, the overall best agreement between observations and MATCH simulations was obtained for the $\mathrm{v}_{d \mathrm{O} 3}=0.01 \mathrm{~cm} \mathrm{~s}^{-1}$ and $0.00 \mathrm{~cm} \mathrm{~s}^{-1}$ scenarios. Interestingly, the relative hourly variability in those data sets with overlapping hourly model and measurement data (Barrow, Pallas-Sammaltunturi, Vindeln and Zeppelinfjellet) also show best agreement for the $\mathrm{v}_{d} \mathrm{O} 3=0.01$ ( 3 times) and $\mathrm{v}_{d \mathrm{O} 3=0.00}(1$ time) scenarios. At higher ozone deposition velocities, air that has resided in the surface layer for longer times will have higher ozone depletion rates, which causes a higher relative ozone variability in air that is transported to the monitoring station. These two findings are in agreement with the spatial January analysis presented above, which also suggested that the $\mathrm{v}_{d \mathrm{O} 3}=0.01$ and $0.00 \mathrm{~cm} \mathrm{~s}^{-1}$ cases yielded the best agreement between observations and model results.

A complication of such a comparison is the heterogeneity of the landscape surrounding the measurement stations. As shown in Fig. 1 many of these sites are located in coastal regions. Consequently, comparison of the simulated ozone concentrations for the applied T42 model resolution, which resembles grid squares of about $250 \times 250 \mathrm{~km}^{2}$, has been subject to a careful selection of grid squares to avoid a 

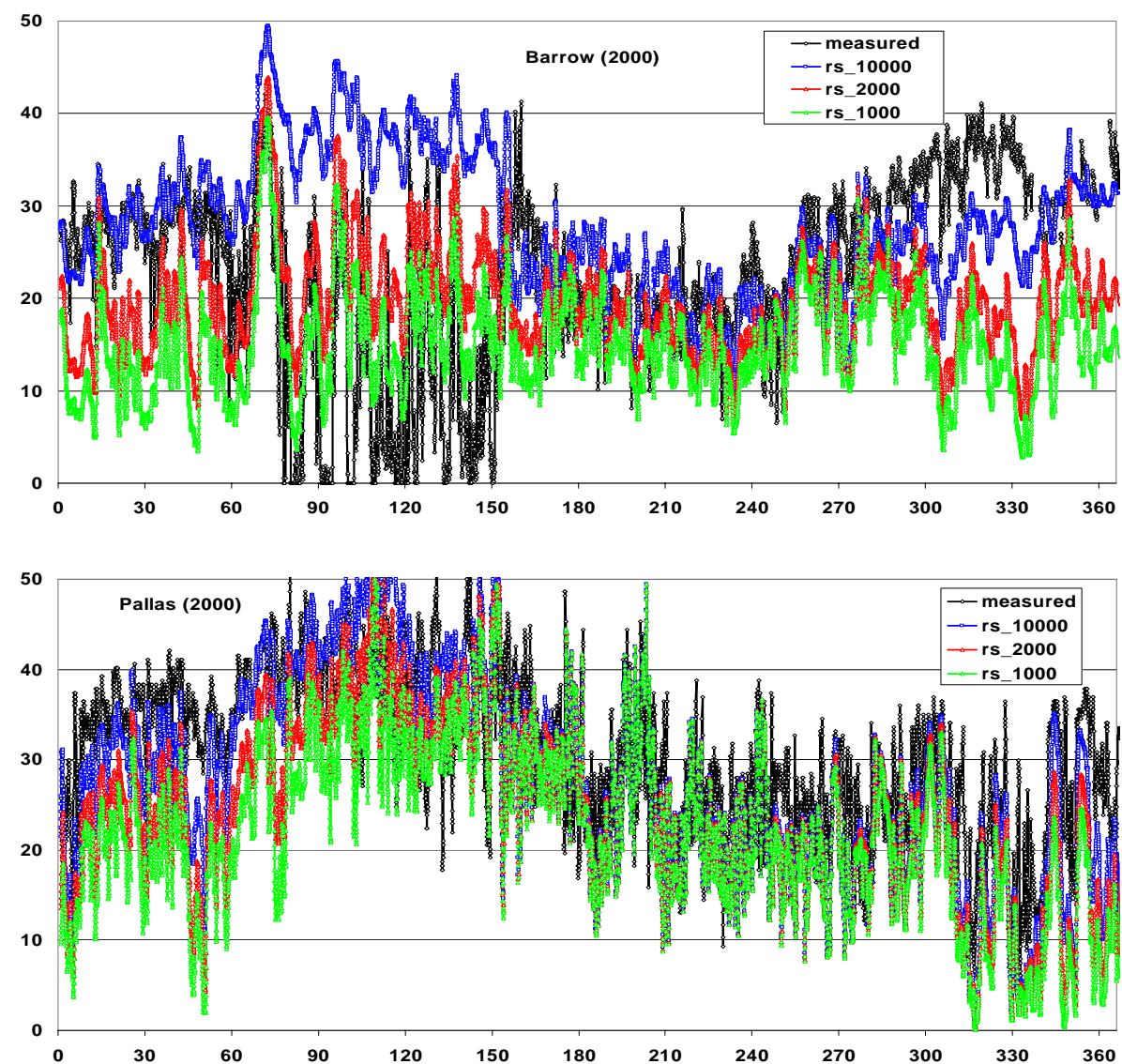

Fig. 6a. Comparison of hourly ozone (in ppbv) for Barrow and Pallas-Sammaltunturi with MATCH simulations at three different ozone-tosnow uptake resistances (Rs=10 000 [blue], 2000 [red] and $1000 \mathrm{~m} \mathrm{~s}^{-1}$ [green]) plotted against the year running day. Measured and modeled data are for year 2000.

comparison between simulated and observed ozone concentrations at a very different altitude or different surface cover. The fact that most coastal sites are bordering the ocean, which is covered with sea ice during the winter months, ensures a fair comparison with respect to model and on-site surface cover since the dry deposition calculations over sea ice apply the same surface uptake resistance as that of snow. Summit is a site where both model elevation and land snow cover are consistent with the actual conditions. As noted earlier, surface ozone at Summit is significantly enhanced compared to other Arctic locations. Even though stratospheretroposphere exchange is considered in $\mathrm{MATCH}$, all model runs $\left(\mathrm{v}_{d \mathrm{O}}=0.00\right.$ to $\left.\mathrm{v}_{d} \mathrm{O} 3=0.10\right)$ yield ozone mixing ratios that are lower (8 to $18 \mathrm{ppbv}$, respectively) than observations, suggesting a possible underestimation of the simulated contribution of stratosphere-troposphere exchanges to surface layer ozone at this site. Notably, all lower altitude stations show better agreement than for Summit.

It is obvious that the sensitivity of the simulated ozone depends on the fetch with snow and sea-ice cover. For instance, relatively small changes were calculated for Keflavik at the southwest coast of Iceland. In contrast, at sites surrounded by a long fetch with snow and sea-ice cover, e.g. Alert, Eureka and Resolute, $\mathrm{O}_{3}$ concentrations for the $\mathrm{v}_{d O 3}=0.01$ simulations are about two times the $\mathrm{v}_{d \mathrm{O} 3}=0.10$ results. The largest sensitivity is found for Barrow, Alaska, where $\mathrm{O}_{3}$ increases from $\sim 11$ to $27 \mathrm{ppbv}$ from a decrease in $\mathrm{v}_{d \mathrm{O}}$ from 0.10 to $0.01 \mathrm{~cm} \mathrm{~s}^{-1}$.

In a different model run, an ozone emission flux as suggested by Galbally and Allison (1972); Zeller and Hehn (1996) and Zeller (2000) was applied. An ozone flux estimate of $0.2 \mu \mathrm{g} \mathrm{m}^{-2} \mathrm{~s}^{-1}$, equivalent to a $\mathrm{v}_{\mathrm{dO}}=-0.3 \mathrm{~cm} \mathrm{~s}^{-1}$ (Zeller, 2000) was used as a 24-h average ozone emission rate. These calculations yielded unrealistic ozone enhancements at high northern latitudes, reaching $>10 \mathrm{ppbv}$ above the $\mathrm{v}_{d \mathrm{O} 3=0.00}$ calculations. These ozone concentrations are in clear disagreement with the station observations and infer that the snowpack ozone emission fluxes reported in the literature (Table 1) can not be deemed representative for January, $\mathrm{NH}$ snow-covered regions.

Records from four stations with continuous hourly data were also compared with the full-year MATCH model 

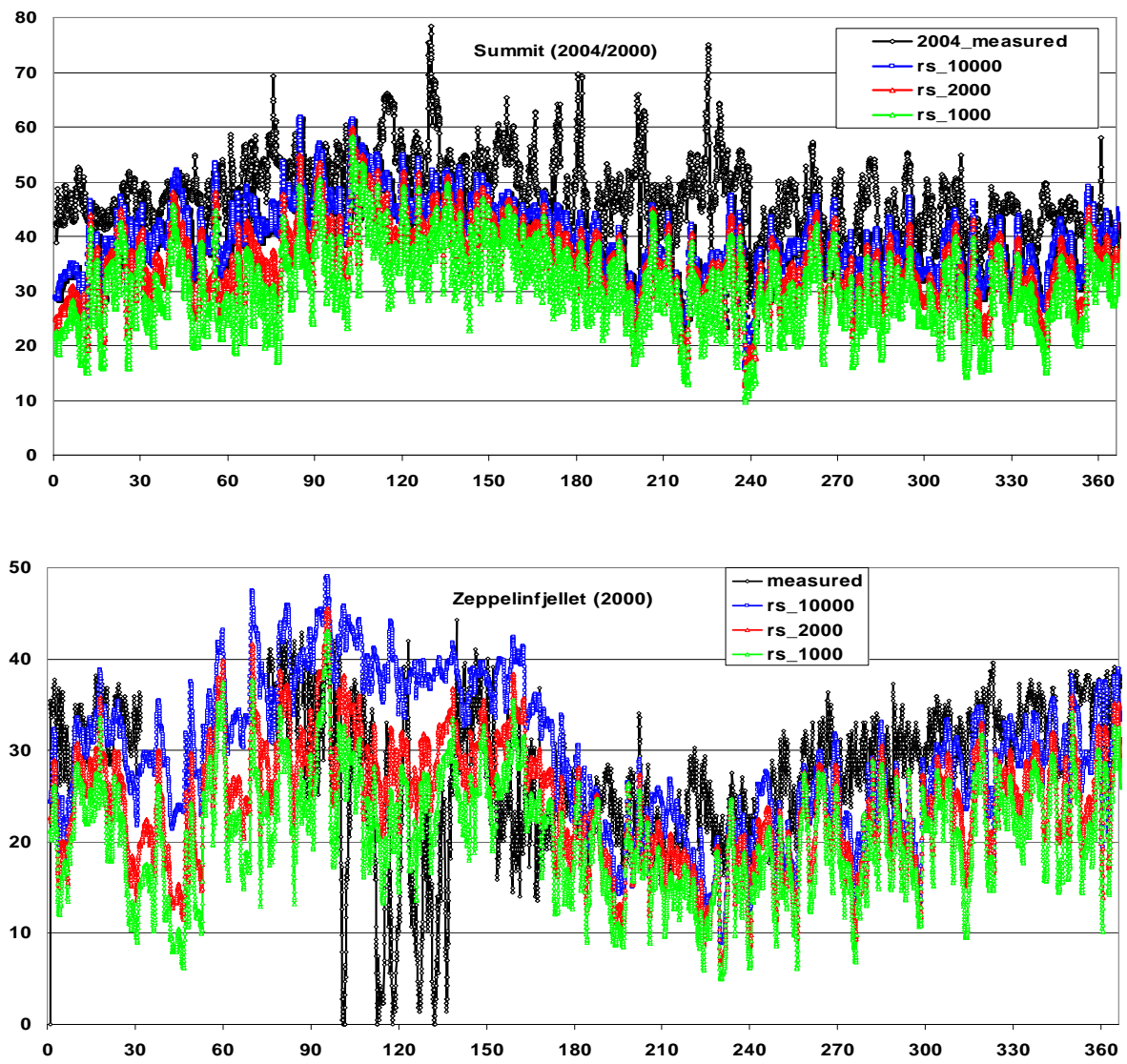

Fig. 6b. Comparison of hourly ozone (in ppbv) for Summit and Zeppelinfjellet with MATCH simulations at three different ozone-to-snow uptake resistances ( $\mathrm{Rs}=10000$ [blue], 2000 [red] and $1000 \mathrm{~m} \mathrm{~s}^{-1}$ [green]) plotted against the year running day. Measured and modeled data are for year 2000 for Zeppelinfjellet. For Summit (lacking a year-round 2000 ozone record) the 2004 measured data are compared with the year 2000 model results.

simulations. The year 2000 ozone data from Barrow, Zeppelinfjellet and Pallas-Sammaltunkuri and 2004 data for Summit (ozone was only recorded during part of 2000) were compared with the MATCH simulations (using year 2000 meteorological data fields). The results of these analyses are presented in Fig. 6. For all sites investigated, best agreement is found for the year-round $\mathrm{v}_{d \mathrm{O}}$, snow $=0.01,0.00$ calculations $\left(\mathrm{v}_{d \mathrm{O}}\right.$, snow $=0.00$ calculations were not included in the figures for clarity). Larger ozone deposition rates do consistently result in significant underestimations of surface ozone.

For all sites the annual cycle in surface ozone is generally well reproduced. A discrepancy between observations and MATCH is evident during spring for the coastal locations. Both Barrow and Zeppelinfjellet are impacted by episodic springtime ozone depletion events. Since solar sunrise halogen chemistry is not represented in MATCH these effects do not show up in the MATCH results. It is important to note that snow cover at Barrow, Pallas-Sammaltunkuri and Zeppelinfjellet changes through the year. Lacking snow during the summer, the calculations are not sensitive to changes to

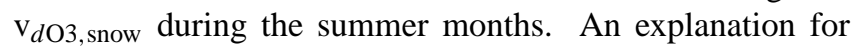

the underestimation of the November ozone concentrations at Barrow might be a too late onset of the snow-sea ice cover in MATCH. The generally good representation of the simulated absolute ozone levels as well as the changes in the seasonal cycle, neglecting the springtime ozone-halogen chemistry, points out that the springtime ozone depletion events, while of high significance at the local scale, does not seem to have a strong influence on the large-scale annual ozone budget.

Figure 7 shows a comparison between the January 2000 simulated and observed ozone mixing ratios at Barrow to demonstrate in more detail the simulated and observed variability in surface ozone as a function of $\mathrm{v}_{d} \mathrm{O} 3$ at this site. It is clearly visible that the $\mathrm{v}_{d \mathrm{O} 3}=0.01 \mathrm{~cm} \mathrm{~s}^{-1}$ simulation reproduces the absolute ozone mixing ratios at Barrow, as well as the temproral variability, much better compared to the higher deposition calculations. For example, the model captures the decrease to $<25$ ppbv on 11-13 January, which is followed by a strong increase to about 35 ppbv on 14 January. The latter event reflects conditions where transport and chemistry become more relevant compared to surface 


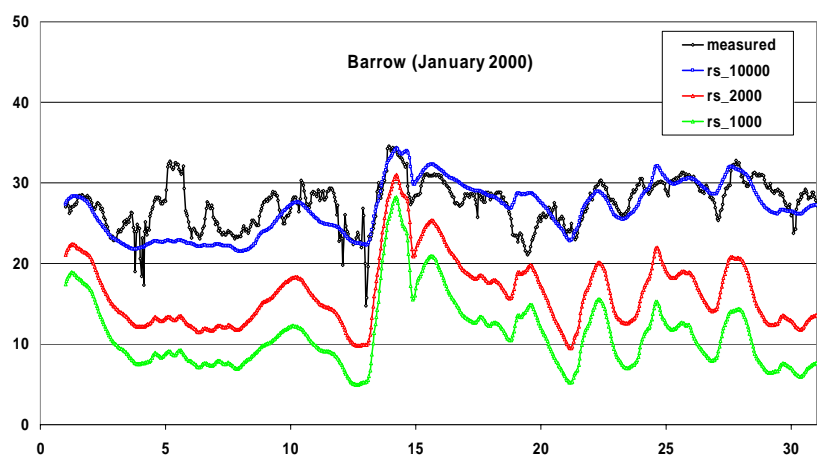

Fig. 7. Comparison of hourly ozone data (in ppbv) at Barrow for January 2000 in comparison with MATCH simulations at three different ozone-to-snow uptake resistances (Rs=10000 [blue], 2000 [red] and $1000 \mathrm{~m} \mathrm{~s}^{-1}$ [green]).

deposition indicated by the low sensitivity to dry deposition during that event in contrast to the rest of the month. The significantly better representation of the temporal variability in ozone concentrations for the low deposition simulation is also clearly visible during an extended period at the end of January, where the high-deposition simulations show a significantly larger change ( $>8 \mathrm{ppbv}$ ) compared to the observed changes of about 5-6 ppbv.

Unfortunately, none of the available data sets appear suitable for an evaluation of the summertime ozone deposition to snow. Barrow, Pallas and Zeppelinfjellet lack snow cover during summer. For Summit, the overall sensitivity to the ozone deposition rate is not that large despite the long fetch with snow cover at this location. This suggests that boundary layer ozone at Summit is less sensitive to deposition, possibly due to the fact that Summit mostly receives free lower to midtropospheric air rather than air that has been transported upslope to the top of the Greenland ice sheet and that has resided in contact with the surface layer for an extended time (Cohen et al., 2006; Helmig et al, 2006d). Given these constraints neither of these comparisons appear well suited to evaluate the ozone deposition to snow-covered land or sea-ice during the summer months, when high solar radiation and snowpack photochemistry may significantly alter ozone surface fluxes.

\section{Conclusions}

The wintertime ozone lifetime in high northern latitudes approaches several months due to low photochemical depletion rates. Even though absolute values of ozone surface fluxes to snow are low compared to ozone fluxes in other continental environments, under these conditions ozone deposition becomes a determining process for surface layer ozone. It appears that many of the published experimental data of ozone fluxes to snow are not a representative description of wintertime and year-round ozone surface fluxes over snow-covered landscapes, in particular over the vast polar regions.
Ozone deposition rates over summertime, sunlit snow can not be conclusively evaluated with this comparison because most of the sites lack extensive snow-covered footprints during summer. Transport phenomena appear to have a strong influence on surface ozone at Summit and reduce the sensitivity towards ozone deposition in this large-scale analysis during the summer months. Improvements in the description of ozone deposition fluxes to sunlit, summertime snowpack are anticipated from recent, direct ozone flux measurements at Summit (Bocquet et al., 2006b).

Similar to other global atmospheric chemistry models that have been described in the literature, MATCH lacks most of the parameterizations that determine variations in ozone fluxes to snow. Important processes that influence surface ozone chemistry and fluxes in the Arctic, e.g. ozone depletion associated with halogen chemistry and oxidized nitrogen chemistry processes in the sunlit snowpack (photodenitrification) are neglected. Despite these deficiencies and discrepancies in the model results versus observations during springtime ozone depletion events, the seasonal ozone cycle is generally well represented by the model, indicating the predominant influence of free-tropospheric ozone chemistry and transport over surface processes on the absolute ozone levels and the seasonal cycle of polar, tropospheric ozone.

These modeling exercises illustrate the sensitivity of surface ozone in the Arctic towards surface deposition processes and as such point out the relevance of a better quantification and representation of ozone snow-ice deposition in largescale atmospheric chemistry models. Comparison of ozone measurements with MATCH simulations indicate that an ozone deposition velocity of no larger than $\mathrm{v}_{d \mathrm{O} 3}=0.01 \mathrm{~cm} \mathrm{~s}^{-1}$ yields the best representation of the ambient data for the month of January. Based on this analysis we suggest applying a snow-ice resistance of $\sim 10000 \mathrm{~s} \mathrm{~m}^{-1}$ for ozone dry deposition calculations in large-scale chemistry and transport models. This value is significantly larger compared to the estimated value of $2000 \mathrm{~s} \mathrm{~m}^{-1}$ that has been previously applied in models such as MATCH and the chemistry-climate model ECHAM4.

Photochemical processes occurring in the snow and above the snow surface are expected to additionally contribute to observed ozone fluxes over snow. The ozone chemistry that has been observed in the surface layer at South Pole, Antarctica, with ozone being formed above the snow and likely being transported out of the surface layer, is currently not represented in the models. The dynamics of ozone in the Antarctic surface layer may ultimately yield the key to explaining the upwards ozone fluxes that were reported in the earlier literature. The ozone production chemistry in Antarctica has been linked to the accumulation of $\mathrm{NO}_{\mathrm{x}}$ in a shallow, highly stable boundary layer under continuous solar irradiance. Current models lack the mechanisms for generation of $\mathrm{NO}_{\mathrm{x}}$ fluxes coming out of the snow, the vertical resolution to properly describe the surface layer $\mathrm{NO}_{\mathrm{x}}$ and ozone chemistry, and have weaknesses in describing transport processes 
under very stable conditions, a situation that is abundantly present over snow.

A compelling question is how previous and anticipated future changes in snow cover will feedback on the tropospheric ozone budget. Changes in global snow-cover and sea-ice extent are becoming increasingly evident (Serreze et al., 2000; ACIA, 2004; Overpeck et al., 2005). The reduction of snowcover will most likely accelerate in a future, warmer climate. Even though large uncertainties exist, literature data on ozone deposition velocities over snow are generally lower than those reported over non-snow-covered landscapes. Furthermore, under most circumstances, loss of snow-cover will result in an increase in the surface roughness, decrease in the surface albedo and increased convective mixing. Taken together, these effects imply that ozone deposition fluxes may increase under these conditions, and may result in reduced surface layer ozone. Reduced snow cover over land will also alter the winter and springtime soil temperatures, which will likely cause changes in soil biogeochemistry (Monson et al., 2006, and references therein). This is expected to influence soil-fluxes of NO and possibly surface layer ozone chemistry. Improvements in both experimental data and parameterizations are needed for an assessment of the overall impact of these diverse processes on boundary layer ozone over snowcovered environments.

Acknowledgements. This manuscript was prepared while the authors were supported through several research projects funded by the United States National Science Foundation (NSF-OPP0240976, OPP-0230046, OPP-0137538, CHE-BE-0410058). Any opinions, findings, and conclusions expressed in this material are those of the authors and do not necessarily reflect the views of the National Science Foundation. We appreciate the hard work of many anonymous colleagues who conducted and archived the ozone data that we used for the model evaluation.

Edited by: W. E. Asher

\section{References}

ACIA (Arctic Climate Impact Assessment): Impacts of a Warming Arctic, Cambridge University Press, Cambridge Univ. Press, New York, 2004.

Aldaz, L.: Flux measurements of atmospheric ozone over land and water, J. Geophys. Res., 74, 6943-6946, 1969.

Albert, M. R., Grannas, A. M., Bottenheim, J., Shepson, P. B., and Peron Jr., F. E.: Processes and properties of snow-air transfer in the High Arctic with application to interstitial ozone at Alert, Canada, Atmos. Environ., 36, 2779-2787, 2002.

Albert, M. R. and Shultz, E. F.: Snow and firn properties and airsnow transport processes at Summit, Greenland, Atmos. Environ., 36, 2789-2797, 2002.

Anlauf, K. G., Mickle, R. E., and Trivett, N. B. A.: Measurement of ozone during polar Sunrise Experiment 1992, J. Geophys. Res., 99, 25 345-25 353, 1994.

Atlas, E. L., Ridley, B. A., and Cantrell, C.: The Tropospheric Ozone Production about the Spring Equinox (TOPSE) experiment: Introduction, J. Geophys. Res., 108, 8353, doi:10.1029/2002JD003172, 2003.

Barrie, L. A., Bottenheim, J. W., Rasmussen, R. A., Schnell, R. C., and Crutzen, P. J.: Ozone destruction and photochemical reactions at polar sunrise in the lower Arctic troposphere, Nature, 334, 138-141, 1988.

Barrie, L. A., Bottenheim, J. W., and Hart, W. R.: Polar sunrise experiment 1992 (PSE-1992) - Preface, J. Geophys. Res., 99, 25 313-25 314, 1994.

Barrie, L. and Platt, U.: Arctic tropospheric chemistry: An overview, Tellus Series B - Chemical and Physical Meteorology, 49, 450-454, 1997.

Bocquet, F., Helmig, D., and Oltmans, S. J.: Ozone in interstitial air of the mid-latitude seasonal snowpack at Niwot Ridge, Colorado, J. Arctic, Antarctic and Alpine Research, in press, 2006a.

Bocquet, F., Cohen, L., and Helmig, D.: Spring- and summer-time atmosphere ozone fluxes above the polar snowpack at Summit, Greenland, Poster presented at the European Geophysical Union Meeting, Vienna, Austria, 2-7 April 2006b.

Bottenheim, J. W., Gallant, A. G., and Brice, K. A.: Measurements of NOy species and $\mathrm{O} 3$ at $82^{\circ} \mathrm{N}$ latitude, Geophys. Res. Lett., 13, 113-116, 1986.

Bottenheim, J. W., Barrie, L. A., Atlas, E., Heidt, L. E., Niki, H., Rasmussen, R. A., and Shepson P. B.: Depletion of lower tropospheric ozone during Arctic spring: the polar Sunrise Experiment 1988, J. Geophys. Res., 95, 101-127, 1990.

Bottenheim, J. W., Fuentes, J. D., Tarasick, D. H., and Anlauf, K. G.: Ozone in the Arctic lower troposphere during winter and spring 2000 (ALERT2000), Atmos. Environ. 36, 2535-2544, 2002.

Brasseur, G. P., Hauglustaine, D. A., Walters, S., Rasch, P. J., Muller, J. F., Granier, C., and Tie X. X.: MOZART, a global chemical transport model for ozone and related chemical tracers. 1. Model description, J. Geophys. Res., 103, 28 265-28 289, 1998.

Chen, G., Davis, D., Crawford, J., Hutterli, L. M., Huey, L. G., Slusher, D., Mauldin, L., Eisele, F., Tanner, D., Dibb, J., Buhr, M., McConnell, J., Lefer, B., Shetter, R., Blake, D., Song, C. H., Lombardi, K., and Arnoldy, J.: A reassessment of HOx South Pole chemistry based on observations recorded during ISCAT 2000, Atmos. Environ., 38, 5451-5461, 2004.

Cieslik, S. A.: Ozone uptake by various surface types: a comparison between dose and exposure, Atmos. Environ., 38, 2409-2420, 2004.

Cohen, L., Helmig, D., Grachev, A., Neff, W., and Fairall, C.: Boundary-layer dynamics and its influence on atmospheric chemistry at Summit, Greenland, Atmos. Environ., in press, 2006.

Colbeck, I. and Harrison, R. M.: Dry deposition of ozone - Some measurements of deposition velocity and of vertical profiles to 100-meters, Atmos. Environ., 16, 1807-1818, 1985.

Cotter, E. S. N., Jones, A. E., Wolff, E. W., and Bauguitte, S. J.B.: What controls photochemical NO and $\mathrm{NO} 2$ production from Antarctic snow? Laboratory investigation assessing the wavelength and temperature dependence, J. Geophys. Res., 108, 4147, doi:10.1029/2002JD002602, 2003.

Crawford, J. H., Davis, D. D., Chen, G., Buhr, M., Oltmans, S., Weller, R., Mauldin, L., Eisele, F., Shetter, R., Lefer, B., Arimoto, R., and Hogan, A.: Evidence for photochemical produc- 
tion of ozone at the South Pole surface, Geophys. Res. Lett., 28, 3641-3644, 2001.

Crutzen, P. J. and Zimmermann, P. H.: The changing photochemistry of the troposphere, Tellus, 43AB, 136-151, 1991.

Davis, D., Nowak, J. B., Chen, G., Buhr, M., Arimoto, R., Hogan, A., Eisele, F., Mauldin, L., Tanner, D., Shetter, R., Lefer, B., and McMurry, P.: Unexpected high levels of NO observed at South Pole, Geophys. Res. Lett., 28, 3625-3628, 2001.

Davis, D. D, Eisele, F., Chen, G., Crawford, J., Huey, G., Tanner, D., Slusher, D., Mauldin, L., Oncley, S., Lenschow, D., Semmer S., Shetter, R., Lefer, B., Arimoto, R., Hogan, A., Grube, P., Lazzara, M., Bandy, A., Thornton, D., Berresheim, H., Bingemer, H., Hutterli, M., McConnell, J., Bales, R., Dibb, J., Buhr, M., Park, J., McMurry, P., Swanson, A., Meinardi, S., and Blake, D.: An overview of ISCAT 2000, Atmos. Environ. 38, 5363-5373, 2004a.

Davis, D., Chen, G., Buhr, M., Crawford, J., Lenshow, D, Lefer, B., Shetter, R., Eisele, F., Mauldin, L., and Hogan, A.: South Pole NOx chemistry: An assessment of factors controlling variability and absolute levels, Atmos. Environ., 38, 5375-5388, 2004b.

Dentener, F., Stevenson, D., Cofala, J., Mechler, R., Amann, M., Bergamaschi, P., Raes, F., and Derwent, R.: The impact of air pollutant and methane emission controls on tropopspheric ozone and radiative forcing: CTM calculations for the period 19902030, Atmos. Chem. Phys., 5, 1731-1755, 2005, http://www.atmos-chem-phys.net/5/1731/2005/.

Dibb, J. E., Talbot, R. W., Munger, J. W., Jacob, D. J., and Fan, S. M.: Air-snow exchange of $\mathrm{HNO}_{3}$ and $\mathrm{NO}_{\mathrm{y}}$ at Summit, Greenland, J. Geophys. Res., 103, 3475-3486, 1998.

Dibb, J. E., Arsenault, M., Peterson, M. C., and Honrath, R. E.: Fast nitrogen oxide photochemistry in Summit, Greenland snow, Atmos. Environ., 36, 2501-2512, 2002.

Dibb, J. E. and Arsenault M.: Shouldn't snowpacks be sources of monocarboxylic acids?, Atmos. Environ., 36, 2513-2521, 2002.

Domine, F. and Shepson, P. B.: Air-snow interactions and atmospheric chemistry, Science, 297, 1506-1510, 2002.

Emmons, L. K., Hess, P., Klonecki, A., Tie, X., Horowitz, L., Lamarque, J. F., Kinnison, D., Brasseur, G., Atlas, E., Browell, E., Cantrell, C. Eisele, F., Mauldin, R.L., Merrill, J., Ridley, B., and Shetter R.: Budget of tropospheric ozone during TOPSE from two chemical transport models, J. Geophys. Res., 108, 8372, doi:10.1029/2002JD002665, 2003.

Fan, S.-M. and Jacob, D. J.: Surface ozone depletion in the Arctic spring sustained by bromine reactions on aerosols, Nature, 359, 522-524, 1992.

Finlayson-Pitts, B. J., Livingstone, R. E., and Berko, H. N.: Ozone destruction and bromine photochemistry at ground level in the arctic spring, Nature, 343, 622-625, 1990.

Foster, K. L., Plastridge, R.A., Bottenheim, J. W., Shepson, P. B., Finlayson-Pitts, B. J., and Spicer, C. W.: The Role of $\mathrm{Br}_{2}$ and $\mathrm{BrCl}$ in Surface Ozone Destruction at polar Sunrise, Science, 291, 471-474, 2001.

Galbally, I. and Allison, I.: Ozone fluxes over snow surfaces, J. Geophys. Res., 77, 3946-3949, 1972.

Galbally, I. E. and Roy, C. R.: Destruction of ozone at the Earth's surface, Quart. J. Roy. Meteorol. Soc., 106, 599-620, 1980a.

Galbally, I. E. and Roy, C. R.: Ozone and nitrogen oxides in the southern hemisphere, Proc. International Ozone Symposium, Boulder, Colorado, pp. 431-438, 1980 b.
Ganzeveld, L. and Lelieveld, J.: Dry deposition parameterization in a chemistry general circulation model and its influence on the distribution of reactive trace gases, J. Geophys. Res., 100, 20 999-21 012, 1995.

Ganzeveld, L., Lelieveld, J., and Roelofs, G.-J.: Dry deposition parameterization of sulfur oxides in a chemistry and general circulation, J. Geophys. Res., 103, 5679-5694, 1998.

Ganzeveld, L., Lelieveld, J., Dentener, F. J., Krol, M. C., Bouwman, A. F., and Roelofs G.-J.: The influence of soil-biogenic NOx emissions on the global distribution of reactive trace gases: the role of canopy processes, J. Geophys. Res., 107, doi:10.1029/2001JD001289, 2002.

Gates, W. L., Boyle, J., Covey, C., Dease, C., Doutriaux, C., Drach, R., Fiorino, M., Gleckler, P., Hnilo, J., Marlais, S., Phillips, T., Potter, G., Santer, B., Sperber, K., Taylor, K., and Williams, D.: An Overview of the Results of the Atmospheric Model Intercomparison Project (AMIP I ), Bull. Am. Meterol. Soc., 73, 1962 1970, 1998.

Gong, S. L., Walmsley, J. L., Barrie, L. A., and Hopper, J. F.: Mechanisms for surface ozone depletion and recovery during polar sunrise, Atmos. Environ., 31, 969-981, 1997.

Helmig, D., Oltmans, S. J., Carlson, D., Lamarque, J. F., Jones, A., Labuschagne, C., Anlauf, K., and Hayden, K.: Surface ozone in polar regions, Atmos. Environ., in press, 2006a.

Helmig, D., Bocquet, F., Cohen, L., and Oltmans, S.: Ozone Uptake to the Summit, Greenland Snowpack, Atmos. Environ., in press, 2006b.

Helmig, D., Johnson, B., Oltmans, S. J., Neff, W., Davis, D. D., and Eisele, F.: Elevated ozone in the boundary-layer at South Pole, Atmos. Environ., in press, 2006c.

Helmig, D., Oltmans, S. J., Morse, T. O., and Dibb, J. E.: What is causing high ozone at Summit, Greenland?, Atmos. Environ., in press, 2006d.

Herstein, U., Grunhage, L., and Jager, H.-J.: Assessment of past, present, and future impacts of ozone and carbon dioxide on crop yields, Atmos. Environ., 29, 2031-2039, 1995.

Honrath, R. E., Peterson, M. C., Guo, S., Dibb, J. E., Shepson, P. B., and Campbell, B.: Evidence of NO production within or upon ice particles in the Greenland snowpack, Geophys. Res. Lett., 26, 695-698, 1999.

Honrath, R. E., Guo, S., Peterson, M., Dziobak, M., Dibb, J. E., and Arsenault, M.: Photochemical production of gas phase NOx from ice crystal $\mathrm{NO}_{3}^{-}$, J. Geophys. Res., 105, 24 183-24 190, 2000a.

Honrath, R. E., Peterson, M. C., Dziobak, M. P., Dibb, J. E., Arsenault, M. A., and Gen, S. A.: Release of NOx from sunlightirradiated midlatitude snow, Geophys. Res. Lett., 27, 2237-2240, 2000b.

Honrath, R. E., Yu, Y., Peterson, M. C., Dibb, J. E., Arsenault, M. A., Cullen, N. J., and Steffen, K.: Vertical fluxes of NOx, HONO, and $\mathrm{HNO}_{3}$ above the snowpack at Summit, Greenland, Atmos. Environ., 36, 2629-2640, 2002.

Hopper, J. F., Barrie, L. A., Silis, A., Hart, W., Gallant, A. J., and Dryfhout, H.: Ozone and meteorology during the 1994 polar Sunrise Experiment, J. Geophys. Res., 103, 1481-1492, 1998.

Hutterli, M. A., Rothlisberger, R., and Bales, R. C.: Atmosphereto-snow-to-firn transfer studies of $\mathrm{HCHO}$ at Summit, Greenland, Geophys. Res. Lett., 26, 1691-1694, 1999.

Hutterli, M. A., Bales, R. C., McConnell, J. R., and Stew- 
art, R. W.: HCHO in Antarctic snow: Preservation in ice cores and air-snow exchange, Geophys. Res. Lett., 29, 1235, doi:10.1029/2001GL014256, 2002.

Impey, G. A., Shepson, P. B., Hastie, D. R., Barrie, L. A., and Anlauf, K. G.: Measurements of Photolyzable Chlorine and Bromine Sources During the polar Sunrise Experiment 1995, J. Geophys. Res., 102, 16005-16010, 1997.

IPCC: Technical Summary. A report accepted by the Working Group I of the Intergovernmental Panel on Climate Change (http: //www.ipcc.ch/), 2001.

Jacobi, H.-W., Frey, M. M., Hutterli, M. A., Bales, R. C., Schrems, O., Cullen, N. J., Steffen, K., and Koehler, C.: Measurements of hydrogen peroxide and formaldehyde exchange between the atmosphere and surface snow at Summit, Greenland, Atmos. Environ., 36, 2619-2628, 2002.

Jones, A. E., Weller, R., Minikin, A., Wolff, E. W., Sturges, W. T., McIntyre, H. P., Leonard, S. R., Schrems, O., and Bauguitte, S.: Oxidized nitrogen chemistry and speciation in the Antarctic troposphere, J. Geophys. Res., 104, 21 355-21 366, 1999.

Jones, A. E., Weller, R., Wolff, E. W., and Jacobi, H. W.: Speciation and rate of photochemical $\mathrm{NO}$ and $\mathrm{NO}_{2}$ production in Antarctic snow, Geophys. Res. Lett., 27, 345-348, 2000.

Jones, A. E., Weller, R., Anderson, P. S., Jacobi, H. W., Wolff, E. W., Schrems, O., and Miller, H.: Measurements of NOx emissions from the Antarctic snowpack, Geophys. Res. Lett., 28, 1499-1502, 2001.

Jones, A. E. and Wolff, E. W.: An analysis of the oxidation potential of the South Pole boundary layer and the influence of stratospheric ozone depletion, J. Geophys. Res., 108, 4565-4572, 2003.

Kalnay, E., Kanamitsu, M., Kistler, R., Collins, W., Deaven, D., Gandin, L., Iredell, M., Saha, S., White, G., Woollen, J., Zhu, Y., Chelliah, M., Ebisuzaki, W., Higgins, W., Janowiak, J., Mo, K. C., Ropelewski, C., Wang, J., Leetmaa, A., Reynolds, R., Jenne, R., and Joseph, D.: The NCEP/NCAR 40 year reanalysis project, Bull. Am. Meteorol. Soc., 77, 437-471, 1996

Lelieveld, J. and Dentener, F. J.: What controls tropospheric ozone?, J. Geophys. Res., 105, 3531-3551, 2000.

Lefohn, A. S. (Ed.): Surface Level Ozone Exposures and Their Effects on Vegetation, Lewis Publishers, 1992.

Lippmann, M.: Health effects of tropospheric ozone, Environ. Sci. Technol., 25, 1954-1962, 1991.

Mickley, L. J., Murti, P. P., Jacob, D. J., Logan, J. A., Koch, D. M., and Rind, D.: Radiative forcing from tropospheric ozone calculated with a unified chemistry-climate model, J. Geophys. Res., 104, 30 153-30 172, 1999.

Monson, R. K., Lipson D. L., Burns, S. P., Turnipseed, A. A., Delany, A. C., Williams, M. W., and Schmidt, S. K.: Winter forest soil respiration controlled by climate and microbial community composition, Nature, 439, 711-714, 2006.

Muller, J. F. and Brasseur G.: IMAGES - A 3-dimensional chemical transport model of the global troposphere, J. Geophys. Res., 100, 16445-16490, 1995.

Munger, J. W., Jacob, D. J., Fan, S.-M., Colman, A. S., and Dibb, J. E.: Concentrations and snow-atmosphere fluxes of reactive nitrogen at Summit, Greenland, J. Geophys. Res., 104, 13721$13734,1999$.

Oltmans, S. J., Schnell, R. C., Sheridan, P. J., Peterson, R. E., Li, S.-M., Winchester, J. W., Tans, P. P., Sturges, W. T., Kahl, J. D., and Barrie, L. A.: Seasonal surface ozone and filterable bromine relationship in the high Arctic, Atmos. Environ., 23, 2431-2441, 1989.

Oncley, S. P., Buhr, M., Lenschow, D. H., Davis, D., and Semmer, S. R.: Observations of summertime NO fluxes and boundarylayer height at the South Pole during ISCAT 2000 using scalar similarity, Atmos. Environ., 38, 5389-5398, 2004.

Overpeck, J. T., Sturm, M., Francis, J. A., Perovich, D. K., Serreze, M. C., Benner, R., Carmack, E. C., Chhapin III, F. S., Gerlach, S. C., Hamilton, L. C., Hinzman, L. D., Holland, M., Huntington, H. P., Key, J. R., Lloyd, A. H., MacDonald, G. M., McFadden, J., Noone, D., Prowse, T. D., Schlosser, P., and Vorosmarty, C.: Arctic system on trajectory to new, seasonally ice-free state, EOS Transactions, 86, 309-312, 2005.

Padro, J., Neumann, H. H., and Den Hartog, G.: Modeled and observed dry deposition velocity of $\mathrm{O}_{3}$ above a deciduous forest in the winter, Atmos. Environ., 26A, 775-784, 1992.

Padro, J.: Seasonal contrasts in modeled and observed dry deposition velocities of $\mathrm{O}_{3}, \mathrm{SO}_{2}$ and $\mathrm{NO}_{2}$ over three surfaces, Atmos. Environ., 27A, 807-814, 1993.

Padro, J.: Summary of ozone dry deposition velocity measurements and model estimates over vineyard, cotton, grass and deciduous forest in summer, Atmos. Environ., 30, 2363-2369, 1996.

Peterson, M. and Honrath, R. E.: Observations of Rapid Photochemical Destruction of Ozone in Snowpack Interstitial Air, Geophys. Res. Lett., 28, 511-514, 2001.

Prinn, R. G., Melillo, J. M., Entekhabi, D., Marshall, J. C., Stone, P. H., Follows, M. J., Hill, C. N., Reilly, J. M., Sokolov, A. P., Wang, C., Kicklighter, D. W., Felzer, B., Zhuang, Q., Tian, H., and McGuire, A. D.: Biocomplexity: Feedbacks between ecosystems and the climate system. Poster presented at the National Science Foundation Meeting "Understanding and Harnessing Complexity in the Environment", Arlington, VA, 21-23 March 2005.

Rankin, A. M., Wolff, E. W., and Martin, S.: Frost flowers: Implications for tropospheric chemistry and ice core interpretation, J Geophys. Res., 107, 4683, doi:10.1029/2002JD002492, 2002.

Rasmussen, A., Kilsholm, S., Sorensen, J. H., and Mikkelsen, I. S.: Analysis of tropospheric ozone measurements in Greenland, Tellus, 49B, 510-521, 1997.

Roeckner, E., Bäuml, G., Bonaventura, L., Brokopf, R., Esch, M., Giorgetta, M., Hagemann, S., Kirchner, L., Kornblueh, L., Manzini, E., Rhodin, A., Schlese, U., Schulzweida, U., and Tompkins, A.: The atmospheric general circulation model ECHAM5. Part I: Model description, Report 349, Max Planck Institute for Meteorology, Hamburg, Germany, available from http://www.mpimet.mpg.de, 2003.

Roesch, A., Wild, M., Gilgen, H., and Ohmura, A.: A new snow cover fraction parameterization for the ECHAM4 GCM, Clim. Dyn., 17, 933-946, 2001.

Roesch, A. and Roeckner, E.: Assessment of snow cover and surface albedo in the ECHAM5 general circulation model, J. Climate, 19, 3828-3843, 2006.

Runeckles, V. C. and Krupa S. V.: The impact of UV-B radiation and ozone on terrestrial vegetation, Environ. Pollut., 83, 191213, 1994.

Serreze, M. C., Walsh, J. E., Chapin, F. S., Osterkamp, T., Dyurgerov, M., Romanovsky, V., Oechel, W. C., Morison, J., Zhang, T., and Barry, R. G.: Observational evidence of recent change in the 
northern high-latitude environment, Clim. Change, 46, 159-207, 2000.

Shepson, P., Matrai, P., Barrie, L., and Botttenheim, J.: OceanAtmosphere-Sea Ice-snowpack interactions in the Arctic, and gloabal change, EOS, 84, 349-355, 2003.

Solberg, S., Schmidtbauer, N., Semb, A., and Stordal, F.: Boundary-layer ozone depletion as seen in the Norwegian Arctic in spring, J. Atmos. Chem., 23, 301-332, 1996.

Staehelin, J., Thudium, J., Buehler, R., Volz-Thomas, A., and Graber W.: Trends in surface ozone concentrations at Arosa (Switzerland), Atmos. Environ., 28, 75-87, 1994.

Stocker, D. W., Zeller, K. F., and Stedman, D. H.: $\mathrm{O}_{3}$ and $\mathrm{NO}_{2}$ fluxes over snow measured by eddy correlation, Atmos. Environ., 29, 1299-1305, 1995.

Sturges, W. T., Schnell, R. C., Landsberger, S., Oltmans, S. J., Harris, J. M., and Li, S.-M.: Chemical and meteorological influences on surface ozone destruction at Barrow, Alaska during spring 1989, Atmos. Environ., 27, 2851-2863, 1993.

Sumner, A. L. and Shepson, P. B.: Snowpack production of formaldehyde and its effect on the Arctic troposphere, Nature, 398, 230-233, 1999.

Swanson, A. L., Blake, N. J., Dibb, J. E., Albert, M. R., Blake, D. R., and Rowland, F. S.: Photochemically induced production of $\mathrm{CH}_{3} \mathrm{Br}, \mathrm{CH}_{3} \mathrm{I}, \mathrm{C}_{2} \mathrm{H}_{5} \mathrm{I}$, ethene, and propene within surface snow at Summit, Greenland, Atmos. Environ., 36, 2671-2681, 2002.

Swanson, A. L., Blake, N. J., Atlas, E., Flocke, F., Blake, D. R., and Rowland, F. S.: Seasonal variations of C $2-C 4$ nonmethane hydrocarbons and C $1-\mathrm{C} 4$ alkyl nitrates at the Summit research station in Greenland, J. Geophys. Res., 108, 4065, doi:10.1029/2001JD001445, 2003.

Taylor, K. E., Williamson, D., and Zwiers, F.: The sea surface temperature and sea-ice concentration boundary conditions for AMIP II simulations, PCMDI Report No. 60, Program for Climate Model Diagnosis and Intercomparison, Lawrence Livermore National Laboratory, Livermore, California, 25 pp., 2000.

Vingarzan, R.: A review of surface ozone background levels and trends, Atmos. Environ., 38, 3431-3442, 2004.

Von Kuhlmann, R., Lawrence, M. G., Crutzen, P. J., and Rasch, P. J.: A model for studies of tropospheric ozone and nonmethane hydrocarbons: Model description and ozone results, J. Geophys. Res., 108, 4294, doi:10.1029/2002JD002893, 2003.

Wang, Y. and Jacob, D. J.: Anthropogenic forcing on tropospheric ozone and $\mathrm{OH}$ since preindustrial times, J. Geophys. Res., 103, 31 123-31 135, 1998.
Wang, Y. H., Shim, S. S., Blake, N., Blake, D., Choi, Y., Ridley, B., Dibb, J., Wimmers, A., Oody, J., Flocke, F., Weinheimer, A., Talbot, R., and Atlas, E.: Intercontinental transport of pollution manifested in the variability and seasonal trend of springtime $\mathrm{O}$ 3 at northern middle and high latitudes, J. Geophys. Res., 108, 4683, doi:10.1029/2003JD003592, 2003.

Weller, R., Minikin, A., Konig-Langlo, G., Schrems, O., Jones, A. E., Wolff, E. W., and Anderson, P. S.: Investigating possible causes of the observed diurnal variability in Antarctic NOy, Geophys. Res. Lett., 26, 2853-2856, 1999.

Wesely, M. L., Cook, D. R., and Williams, R. M.: Field measurement of small ozone fluxes to snow, wet bare soil, and lake water, Boundary-Layer Meteorol., 20, 459-471, 1981.

Wesely, M. M. and Hicks, B. B.: A review of the current knowledge on dry deposition, Atmos. Environ., 34, 2261-2282, 2000.

Yang, J., Honrath, R. E., Peterson, M. C., Dibb, J. E., Sumner, A. L., Shepson, P. B., Frey, M., Jacobi, H.-W., Swanson, A., and Blake, N.: Impacts of snowpack photochemistry on levels of $\mathrm{OH}$ and peroxy radicals at Summit, Greenland, Atmos. Environ., 36 , 2523-2534, 2002.

Yienger, J. J., Klonecki, A. A., Levy II, H., Moxim, W. J., and Carmichael, G. R.: An evaluation of chemistry's role in the winter-spring ozone maximum found in the northern midlatitude free troposphere, J. Geophys. Res., 104, 3655-3667, 1999.

Zeller, K. and Hehn, T.: Wintertime anomalies in ozone deposition above a subalpine spruce-fir forest. Research and Applications of Chemical Sciences in Forestry. Proceedings of the $4^{\text {th }}$ Southern Station Chemical Sciences Meeting. New Orleans, General Technical Report SO-104, 131-138, 1994.

Zeller, K. and Hehn, T.: Ozone deposition in a snow-covered subalpine spruce-fir forest environment. Biogeochemistry of Seasonally Snow-Covered Catchments. Proceedings of a Boulder Symposium, July 1995, IAHS Publ. no 228, pp. 17-22, 1995.

Zeller, K. and Hehn, T.: Measurements of upward turbulent ozone fluxes above a subalpine spruce-fir forest, Geophys. Res. Lett., 23, 841-844, 1996.

Zeller, K.: Wintertime ozone fluxes and profiles above a subalpine spruce-fir forest, J. Appl. Meteorol., 39, 92-101, 2000.

Zhou, X. L., Beine, H. J., Honrath, R. E., Fuentes, J. D., Simpson, W., Shepson, P. B., Bottenheim, J. W.: Snowpack photochemical production of HONO: A major source of $\mathrm{OH}$ in the Arctic boundary layer in springtime, Geophys. Res. Lett., 28, 40874090, 2001. 